San Jose State University

SJSU ScholarWorks

Master's Theses

Master's Theses and Graduate Research

Fall 2011

\title{
Incorporation of Host Rock Blocks During the Growth of the Aztec Wash Pluton, Eldorado Mountains, Nevada
}

Jamie Nicole Smith

San Jose State University

Follow this and additional works at: https://scholarworks.sjsu.edu/etd_theses

\section{Recommended Citation}

Smith, Jamie Nicole, "Incorporation of Host Rock Blocks During the Growth of the Aztec Wash Pluton, Eldorado Mountains, Nevada" (2011). Master's Theses. 4113.

DOI: https://doi.org/10.31979/etd.zdas-tm4s

https://scholarworks.sjsu.edu/etd_theses/4113

This Thesis is brought to you for free and open access by the Master's Theses and Graduate Research at SJSU ScholarWorks. It has been accepted for inclusion in Master's Theses by an authorized administrator of SJSU ScholarWorks. For more information, please contact scholarworks@sjsu.edu. 
INCORPORATION OF HOST ROCK BLOCKS DURING THE GROWTH OF THE AZTEC WASH PLUTON, ELDORADO MOUNTAINS, NEVADA

\author{
A Thesis \\ Presented to \\ The Faculty of the Department of Geology \\ San Jose State University \\ In Partial Fulfillment \\ of the Requirements for the Degree \\ Master of Sciences
}

by

Jamie Nicole Smith

December 2011 
(C) 2011

Jamie Nicole Smith

ALL RIGHTS RESERVED 
The Designated Thesis Committee Approves the Thesis Titled

INCORPORATION OF HOST ROCK BLOCKS DURING THE GROWTH OF THE AZTEC WASH PLUTON, ELDORADO MOUNTAINS, NEVADA

by

Jamie N. Smith

APPROVED FOR THE DEPARTMENT OF GEOLOGY

SAN JOSÉ STATE UNIVERSITY

December 2011

Dr. Jonathan Miller

Department of Geology

Dr. Robert Miller

Department of Geology

Dr. Richard Sedlock

Department of Geology 


\begin{abstract}
INCORPORATION OF HOST ROCK BLOCKS DURING THE GROWTH OF THE AZTEC WASH PLUTON, ELDORADO MOUNTAINS, NEVADA
\end{abstract}

By Jamie N. Smith

The Miocene Aztec Wash pluton, Eldorado Mountains (NV), has been tilted by regional extension and thus provides a vertical cross-section showing $5 \mathrm{~km}$ structural depth. Previous work shows that the Aztec Wash pluton was constructed by vertical accumulation of mafic sheets intruded into granite magma with widespread hybridization. Precambrian orthogneiss and Cretaceous granite host rock xenoliths ( $1 \mathrm{~cm}$ to $>20 \mathrm{~m}$ long dimension) occur at all structural levels but are heterogeneously distributed (locally varying from 0 to $50 \%$ of areal exposure). Their origin and relation to the Aztec Wash pluton are poorly known. Mapping at 1:6000 of a xenolith-rich area has shown that 1) xenolith size and integrity of contacts with surrounding plutonic rock are highly variable; 2) sub-solidus fabrics in xenoliths show no preferred orientation compared to host rocks in the pluton roof; 3) xenoliths display evidence of mechanical disaggregation, but geochemistry suggests minimal assimilation; and 4) draping of sheets over xenoliths indicate they are stratabound within the mafic sheet sequences. These observations, together with documented vertical growth of the pluton and the distribution of host rock xenoliths, suggest episodic detachment and stoping of surrounding host rocks (possibly during eruption) to form xenoliths. 


\section{ACKNOWLEDGMENTS}

I would like to thank my thesis advisor, Dr. Jonathan Miller, for his time, support, knowledge, and friendship. From the classroom to the field I could not have completed this project without his guidance and expertise. NSF grants EAR0409882 and EAR0409876 (to Jonathan Miller and Calvin Miller) provided the funding for this project. I would also like to thank my thesis committee members Dr. Robert Miller and Dr. Richard Sedlock. Their wealth of knowledge, encouragement, and critical eye, have been invaluable. From all of my professors and instructors at SJSU I learned so much, so thank you to the whole department. Dr. Calvin Miller of Vanderbilt University provided expertise in the field, and his insights and thoughts on the project were invaluable. Chris Koteas allowed me the use of his maps and data. Thanks also to Dr. Jim Faulds and Dr. Rod Metcalf for their expertise in the field and in my study area. I would also like to thank all of my field assistants, Jose Eduardo Gonzalez, Brigid Doran, Jason Smith, Jennifer Mendonca, Brendon Johnson, Ryan McKee, and Shannon Leslie. Thank you for

all your hard work, patience, and the fun memories. You guys are the best! Last, but not least, I would like to thank my family . Eduardo, my parents Joan and Gary, and my brothers Jonathon and Jason for their support and their encouragement through this project and every other that I have tackled in my lifetime. I love you! 
TABLE OF CONTENTS

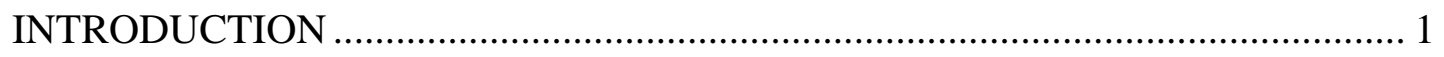

REGIONAL GEOLOGIC SETTING.............................................................. 4

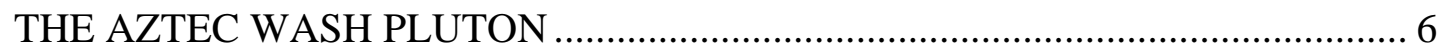

MAPPING AND FIELD RELATIONSHIPS ……………................................ 12

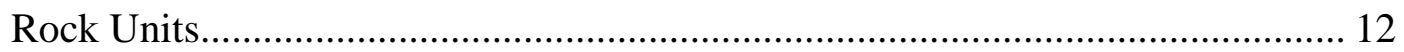

Xenolith Distribution, Size, Contact Relationships, and Fabrics.............................. 15

Mafic and Silicic Sheeted Sequences and Granite Pipes ....................................... 22

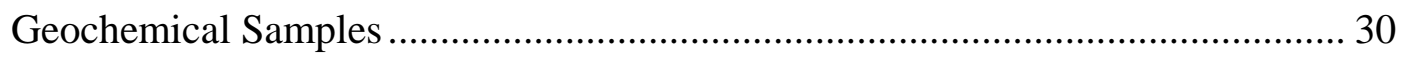

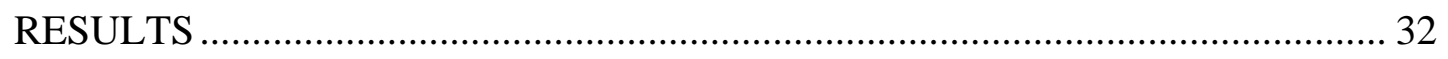

Host Rock and Xenolith Foliations..................................................................... 32

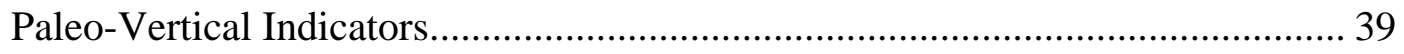

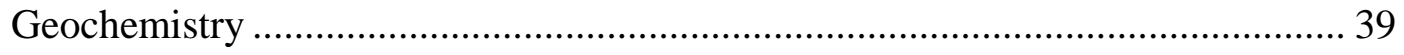

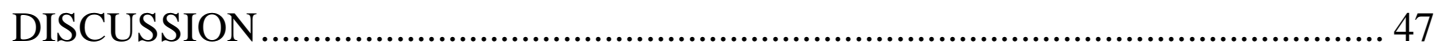

Random Orientations of Foliations ....................................................................... 48

Relationship of Host-Rock Xenoliths to the Sheeted Sequences.............................. 49

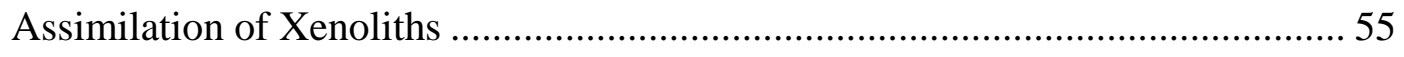

Wider Distribution of Xenolith Blocks in the Heterogeneous Zone........................ 58

Are the Xenoliths Stoped Blocks? ....................................................................... 59

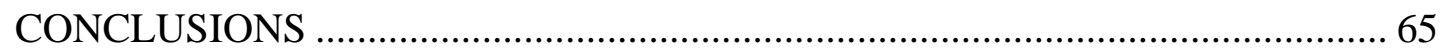

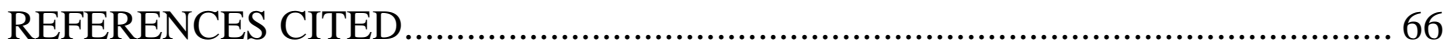




\section{LIST OF FIGURES}

Figure

1. Generalized geologic map of northern Colorado River extensional corridor...... 5

2. Aztec Wash general location map ........................................................... 7

3. Generalized geologic map of Aztec Wash pluton ....................................... 8

4. Sharp and gradational xenolith contact relationships .................................. 17

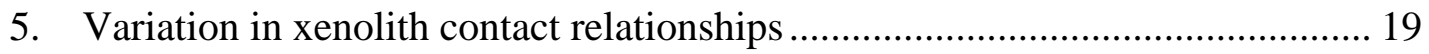

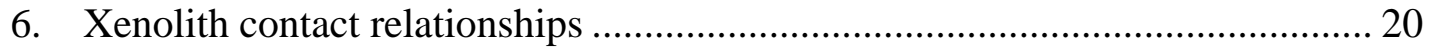

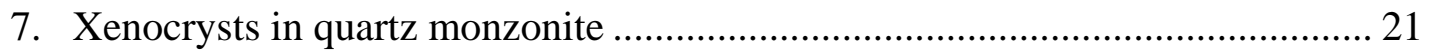

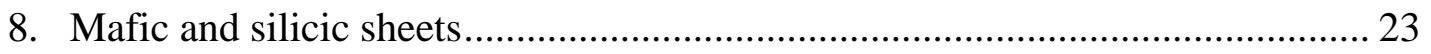

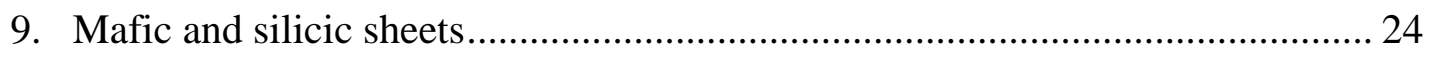

10. Flattened oblate-ellipsoid enclaves in mafic sheet ........................................ 25

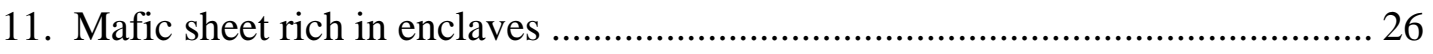

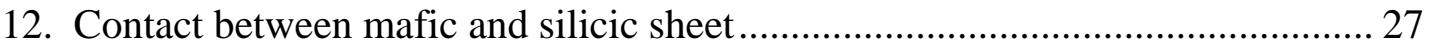

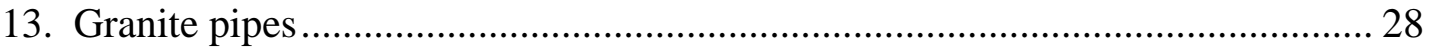

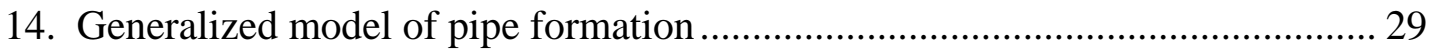

15. Stereographic projection of poles to xenolith foliations .................................. 34

16. Contoured stereographic projection of poles to xenolith foliations.................... 35

17. Stereographic projection of poles to host rock foliations ................................. 36

18. Stereographic projection of poles to sheet orientations .................................. 37

19. Stereographic projection of poles to magmatic foliations ................................ 38

20. Major elements $\mathrm{TiO}_{2}, \mathrm{Al}_{2} \mathrm{O}_{3}, \mathrm{FeO}, \mathrm{MnO}, \mathrm{MgO}$, and $\mathrm{CaO}$ plotted versus $\mathrm{SiO}_{2} 42$

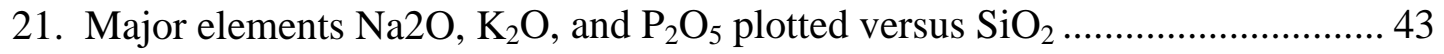

22. Trace elements Ni, Cr, Sc, V, Ba, Rb, Sr, and Zr versus SiO2 ........................ 44 


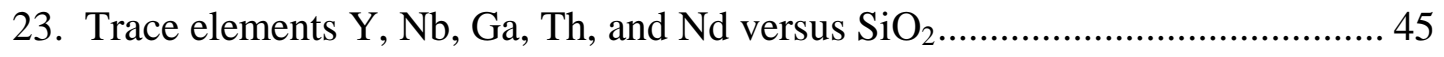

24. Mafic sheet draped over xenolith ............................................................... 51

25. Cartoon diagram of mafic sheet draped over xenolith..................................... 52

26. Steeply tilted mafic sheet sequence ........................................................... 53

27. Cartoon diagram of steeply tilted mafic sheet sequence ................................. 54

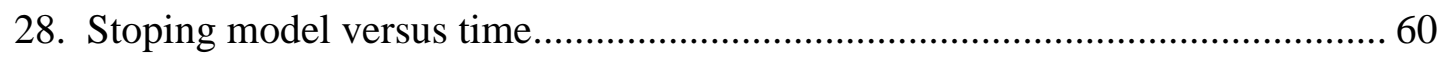

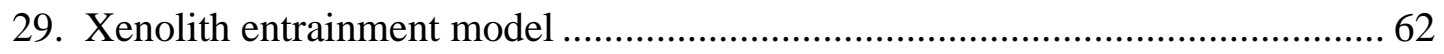




\section{TABLES}

Table

1. Whole Rock Geochemical...........................................40 


\section{LIST OF PLATES}

Plate No.

1. Geologic Map and Xenolith Foliations

2. Xenolith Size and Sheet Distribution Map

3. Sheet Orientation Map 


\section{INTRODUCTION}

The degree to which various material transfer processes operate to make space for magmas as they ascend is still controversial and imperfectly known. Included among these processes are roof uplift, diapirism, cauldron subsidence, downward ductile flow, assimilation, floor sinking (lopolith formation), regional shearing and dilation, and magmatic stoping. (Pitcher and Bussell, 1977; Marsh, 1982; Paterson et al., 1991, 1996; Tikoff and Teyssier, 1992, 1999; Wiebe and Collins, 1998; Miller and Paterson, 1999; McNulty et al., 2000; Cruden and McCaffrey, 2001; Yoshinobu et al., 2003; Dumond et al., 2005; Grocott et al., 2009).

The last mechanism and the subject of this study, magmatic stoping, was first proposed as a significant material transfer mechanism accommodating magma emplacement by Daly (1903). Daly argued that the roof rocks above a body of magma would be subjected to significant thermal stresses, resulting in fracturing of the roof and inevitable downward displacement of roof blocks. The process was envisaged to be analogous to quarrying solid rock by the application of heat.

Recent studies addressing the significance of stoping as a material transfer

process during magma emplacement (e.g., Paterson et al., 1996; Pinotti et al., 2002; Yoshinobu et al., 2003; Hawkins and Wiebe, 2004; Dumond et al., 2005; Titus et al., 2005; Zàk and Paterson, 2006; Pignotta and Paterson, 2007) and on magma chamber chemical evolution (e.g., Clarke et al., 1998, Barnes et al., 2004) have spurred intense debate in the petrologic community, and at least one prominent review by Glazner and Bartley (2006) has questioned the efficiency of stoping in material transfer and in 
chemical modification of magma, arguing that it is a very limited process in the upper crust. The Glazner and Bartley (2006) study generated a string of critical comments that followed its publication (Paterson et al., 2008; Yoshinobu and Barnes, 2008; Clarke and Erdman, 2008). Both the original Glazner and Bartley paper and the Comments and Replies that followed concluded that more studies that can clearly document evidence of stoping are needed.

A serious limitation to addressing material transfer and displacement processes during ascent, collection, and growth of magma bodies is the generally limited exposure in the vertical dimension of individual plutons. Material transfer and displacement of host rocks may operate vertically (e.g., roof uplifting, stoping, floor sinking, downward return flow of host rocks) or laterally (e.g., by tectonic dilation and dike propagation); thus it is vital to examine plutons with depth exposure in a variety of tectonic settings to understand the mechanisms that accommodate emplacement of magma. Appreciable mass transfer by stoping is most likely to occur in the shallow crust (Paterson et al., 1996), and so examination of relatively shallowly emplaced plutons (middle-upper crust) is likely to reveal whether stoping accommodates magma emplacement.

The Aztec Wash pluton in southern Nevada is an ideal intrusion to study in detail with regards to the possible role of magmatic stoping and assimilation in the emplacement and chemical modification of mid- to shallow crustal magma bodies. This is because the Aztec Wash pluton is located in one of the North America's best exposed windows into the crust — the Colorado River extensional corridor (CREC) - where moderate to steep tilting has exposed Miocene plutons from their roofs to several 
kilometers structural depth (Faulds et al., 1990, 2001; Bachl et al., 2001; Walker et al., 2007). 


\section{REGIONAL GEOLOGIC SETTING}

The Colorado River extensional corridor, which includes parts of southern Nevada and western Arizona, is located along the eastern edge of the Basin and Range province (Fig. 1). It varies in width from $50-100 \mathrm{~km}$, and is characterized by moderately to highly extended continental crust (Howard and John, 1987; Faulds et al., 1990, 2001). Rapid and voluminous Miocene magmatism and extreme extension formed the CREC between about $18 \mathrm{Ma}$ and 10-14 Ma. Extension resulted in steeply W- and E-tilted blocks with tilts commonly in excess of 80 degrees and locally overturned. The tilting and deep erosion have produced spectacular cross-sectional views of the Miocene plutons and their overlying volcanic cover (Bachl et al., 2001; Faulds et al., 1995; 2001). In the northern part of the CREC, several of these plutons are well exposed in the Eldorado Mountains alongside the Colorado River. The Eldorado Mountains are located within the larger Mojave Province, which includes Early to Middle Proterozoic rocks as well as some Mesozoic granites (Bennet and DePaolo, 1987; Miller and Wooden, 1990; Patrick and Miller, 1997). 


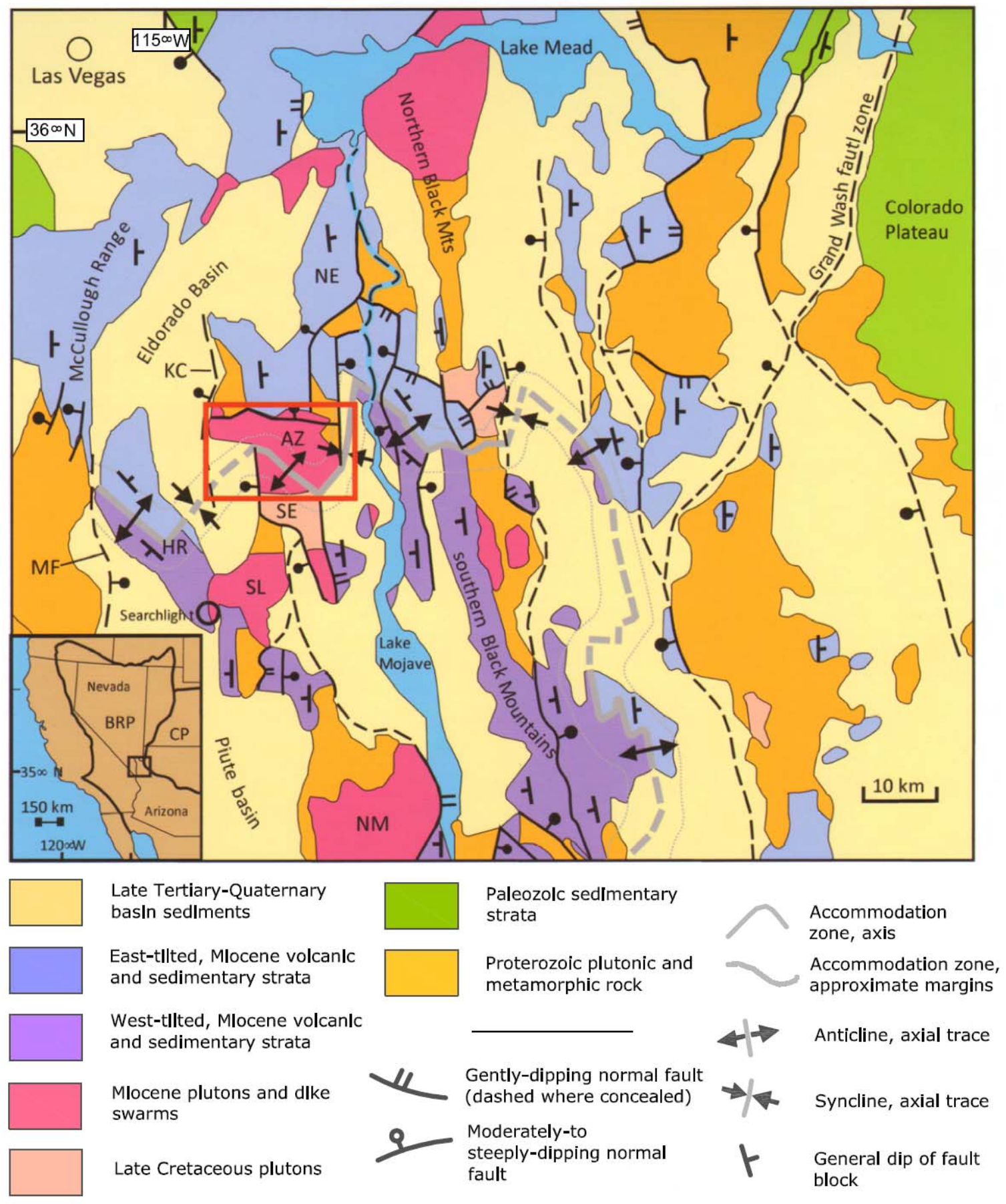

Figure 1. Generalized map of the Colorado River extensional corridor (after Faulds et al., 2001). Box shows the location of the Aztec Wash pluton. HR-Highland Range, MF- McCullough fault, NE-northern Eldorado Mountains, NM-Newberry Mountains, SE-southern Eldorado Mountains, SL-Searchlight pluton. The highly extended northern CREC is bounded by the McCullough fault and the Grand Wash fault zone. 


\section{THE AZTEC WASH PLUTON}

In the Eldorado Mountains, the most extensively studied and well characterized Miocene intrusions are the Aztec Wash pluton and the Searchlight pluton (Falkner et al., 1995; Bachl et al., 2001; Miller and Miller, 2002; Cates, 2003; Coiner et al., 2003;

Harper et al., 2004; Koteas, 2005; Ericksen, 2006). The Aztec Wash pluton, which is the subject of this study, is exposed in the central Eldorado Mountains and is variably tilted to the east-northeast. It sits within an extensional accommodation zone separating easttilted crustal blocks to the north from west-dipping crustal blocks to the south (Faulds et al., 1995) (Figs. 1 and 2). Some east-west extension occurred in conjunction with the emplacement of the Aztec Wash pluton, but most of the tilting occurred after emplacement (Anderson et. al., 1972; Falkner et al., 1995; Gans and Bohrson, 1998).

The Aztec Wash pluton is divided into three structural zones by the Tule Springs, and Pipe Canyon faults (Fig. 3) (Patrick and Miller 1997; Coiner, 2003; Koteas, 2005; Ericksen, 2006). Previous structural studies concluded that, for the exposed portion of the pluton east of the Pipe Canyon fault, moderate to steep tilting to the NE (steeper toward the NE) has occurred (Patrick and Miller 1997; Coiner, 2003; Koteas, 2005; Ericksen, 2006). To the north-northeast, which would be the structural roof of the Aztec Wash pluton, the pluton intrudes Proterozoic gneiss (Falkner et al., 1995; Miller and Miller, 2002). Along its northern margin, which is an exposed "wall" of the pluton, the Aztec Wash pluton intrudes the slightly older, Middle Miocene Nelson pluton and early Miocene Patsy Mine volcanic rocks (Anderson et al., 1971). To the south and west the 


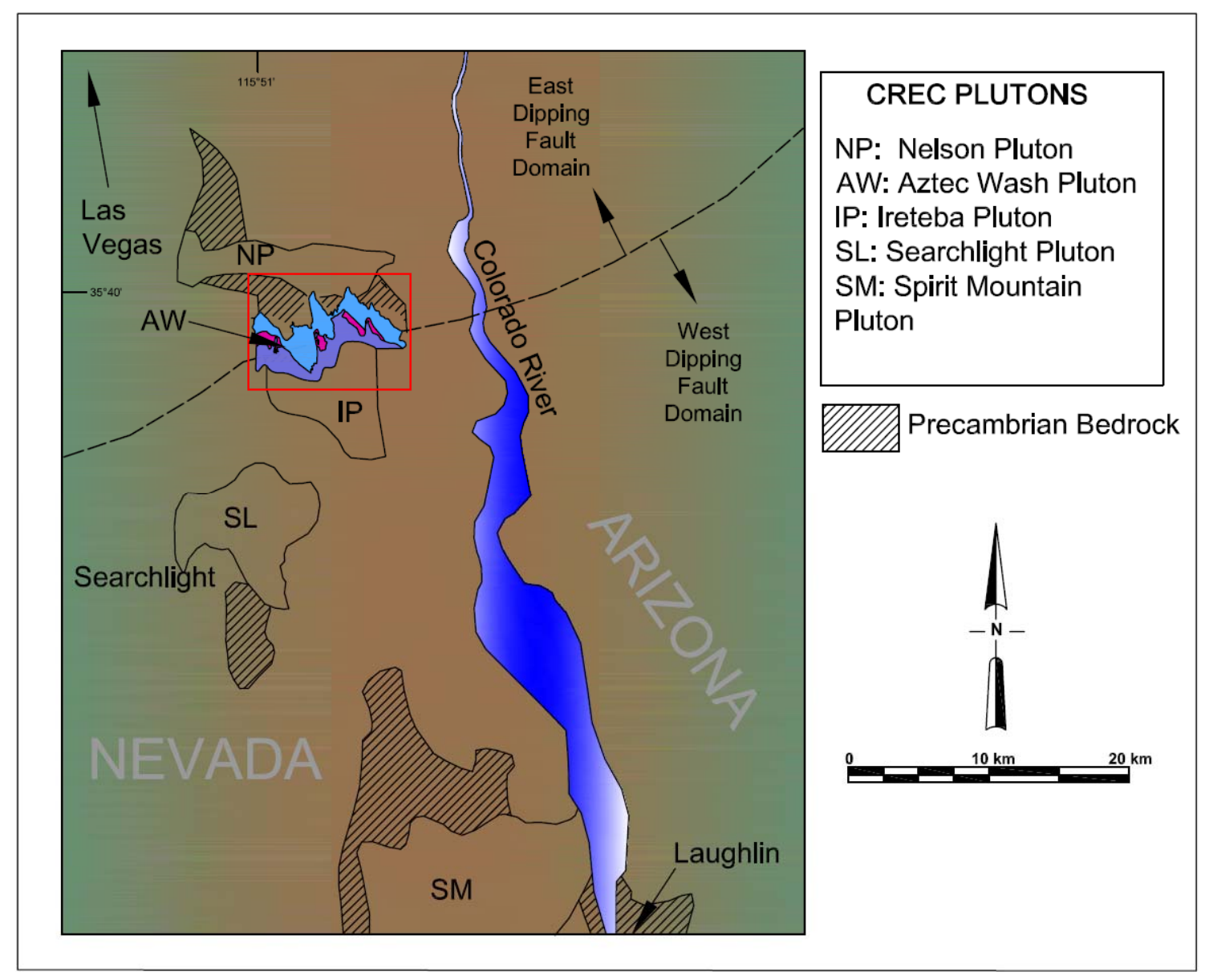

Figure 2. Aztec Wash general location map. The approximate location and orientation of the Aztec Wash pluton within the Colorado River Extensional Corridor (modified from Faulds et al., 2001). 


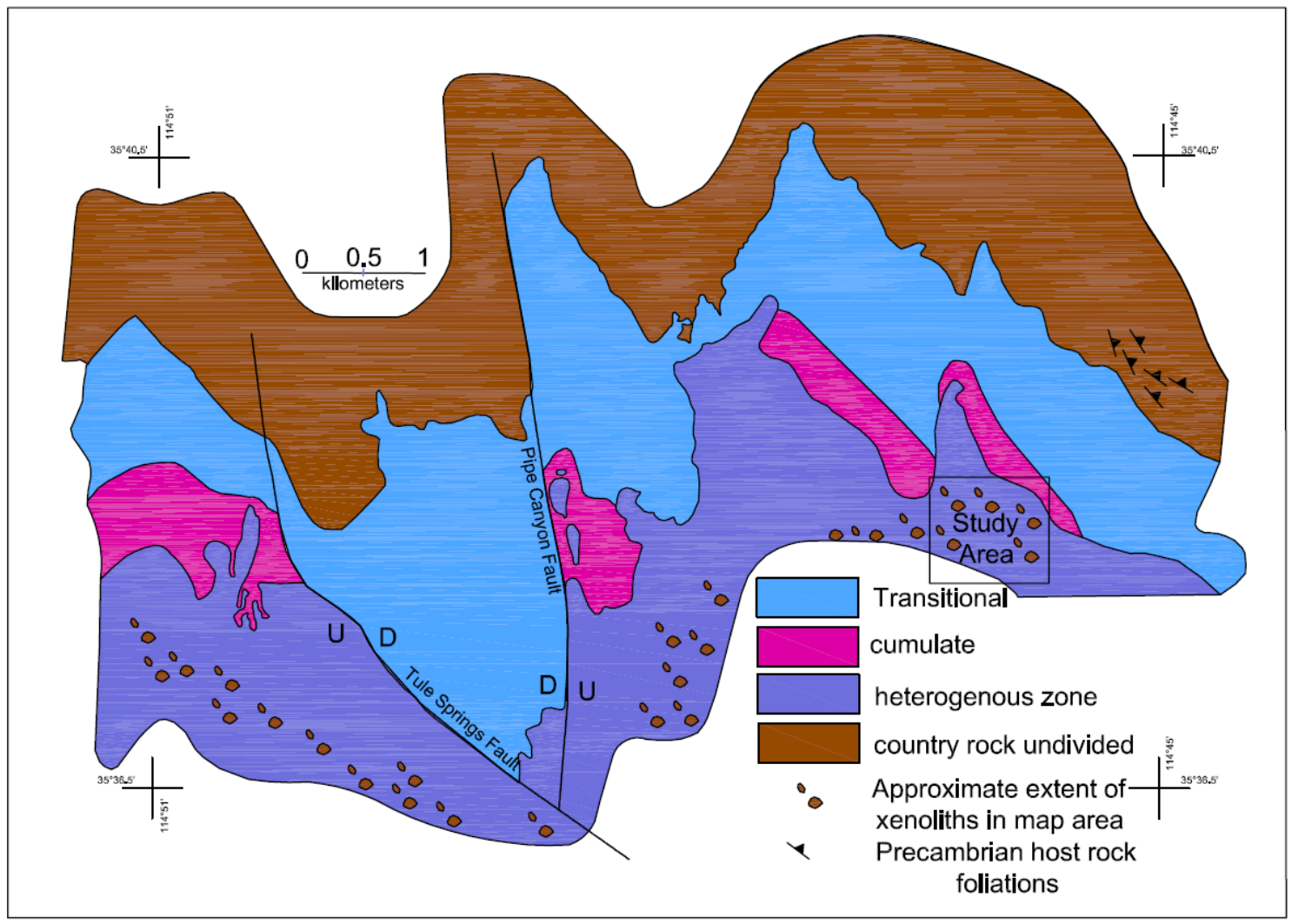

Figure 3. Generalized geologic map of Aztec Wash pluton. The approximate locations of the study area, extent of xenoliths, and strike of adjacent host rock foliations are shown (Modified from Koteas, 2005). 
Aztec Wash pluton intrudes the Cretaceous Ireteba granite; however, much of the southern portion of the pluton is cut off by the Tule Springs fault. The area from east of the Pipe Canyon fault to its eastern exposed limit at the roof represents a continuous section of moderately to steeply tilted Aztec Wash pluton (Fig. 3). Tilting of the pluton has produced a 5-km deep section, and earlier work shows that it was constructed by repeated magma intrusion into an active (waxing and waning) mafic-slicic magma chamber (Miller and Miller, 2002; Coiner, 2003; Harper et al., 2004; Koteas, 2005; Miller et al., 2005; Bleick, 2006; Ericksen, 2006). Harper et al. infer a feeder zone to the south of the main exposures of the pluton but a significant portion of the intrusion is no longer exposed south of the Tule Wash fault.

Previous geologic mapping of Aztec Wash pluton divided it into two broad petrologically distinctive zones: a Granite zone, consisting of a variety of low-to high-silica granites; and a Heterogeneous zone, which comprises rock ranging from low-silica gabbros to high-silica granites, and in which there is significant field, petrographic, and geochemical evidence for interaction and mixing of magmas of different compositions (Falkner et al., 1995; Patrick and Miller, 1997; Robinson and Miller, 1999; Miller and Miller, 2002; Cates et al., 2003; Coiner et al., 2003; Harper et al., 2003; Miller et al., 2003; Harper et al., 2004; Koteas, 2005; Ericksen, 2006). The pluton is also cut by at least three episodes of later mafic and felsic dikes (Harper et al., 2004). In the map area they sharply cut both sheet sequences and xenoliths and are consistent with peak extension in the vicinity of the Aztec Wash pluton (Gans and Bohrson, 1998).

Work on the hybrid rocks in the Heterogeneous zone (detailed below) has shown that the Aztec Wash pluton experienced many episodes of bimodal (mafic-felsic) 
replenishment during its construction, and that hybridization occurred by mechanical mixing as well as diffusive chemical and isotopic exchange (Bleick, 2006; Ericksen, 2006). Geochemical and isotopic data from the mafic rocks suggests they were derived from partial melting of enriched lithospheric mantle, while the granites are formed by input and fractionation of felsic melts derived by crustal anatexis (Harper et al., 2004; Ericksen, 2006). The intermediate rocks span a wide range of rock compositions and show remarkable textural variability. This variation is interpreted to result from mixing of mafic magmas with primary felsic input melts, repeated intrachamber mechanical mixing of mafic intruding magmas with resident felsic magmas, and thermal assimilation of granitic cumulate crystal mush by intruding mafic magmas (Miller and Miller, 2002; Bleick, 2006; Ericksen, 2006).

The Granite zone was described in detail in a study by Harper et al. (2004) who divided it into several distinct units based on composition and texture. Granites in the Granite zone span a compositional range from low silica (ca. $70-72$ wt. \% $\mathrm{SiO}_{2}$ ) to high silica ( $\geq 77$ wt. $\% \mathrm{SiO}_{2}$ ). Crystal size ranges from coarse to fine, with coarse-grained rocks generally more equigranular and fine grained rocks showing more textural variability (aplites and marginal porphyries). Toward the structural roof of the pluton abundant miarolitic (gas) cavities are present in the leucogranites. In addition, felsic elliptical enclaves ranging from a few $\mathrm{cm}$ to $>1 \mathrm{~m}$ diameter are found throughout the Granite zone.

Rock types in the Heterogeneous zone include olivine-bearing gabbros that range from troctolites to coarse-grained hornblende gabbro and diorite, and a large array of texturally variable intermediate rocks (mainly quartz monzonites and quartz 
monzodiorites) and granites. Field evidence of hybridization in the Heterogeneous zone is abundant, and in several areas of the pluton it is possible to find well developed interlayered mafic and felsic sheets that have mingled and/or hybridized contacts. Felsic sheets are typically coarse-grained quartz monzonites, to quartz monzodiorites and are interpreted to be cumulates produced by extraction of granitic magma (Harper et. al 2004; Patrick and Miller, 1997). Felsic pipes are commonly observed extending perpendicular to felsic sheets and passing through adjacent mafic sheets (Patrick and Miller, 1997; Coiner, 2003; Ericksen 2006). The mafic sheets range texturally from coarse gabbros and diorites to fine-grained microgabbro (essentially trachybasalts) that usually are quenched where in contact with the felsic sheets. In addition to these main pluton rocks, host rock xenoliths (centimeters to tens of meters in outcrops) of Proterozoic intermediate to felsic orthogneiss, Proterozoic amphibolite, and Cretaceous Ireteba granite are widespread in part of the Heterogeneous zone. The mafic sheeted sequences, granitic pipes, and way-up indicators provide a constraint on the direction of gravity, and because the sheeted sequences are built sequentially they can be used to examine the relative timing of incorporation of xenoliths into the Aztec Wash as it was being constructed. A similar situation occurs in the Silurian Vinalhaven intrusion of coastal Maine, where Proterozoic xenoliths occur in "stratabound" horizons and are inferred to have been incorporated in the intrusion during during discrete stoping events that accompanied magma chamber eruption (Hawkins and Wiebe, 2004). 


\section{MAPPING AND FIELD RELATIONSHIPS}

The field mapping for the current project was completed exclusively within the Heterogeneous zone, in the east-tilted structural block of the pluton (Fig. 3), and at a scale of 1:6000. The area covers approximately $3.2 \mathrm{~km}^{2}$ and includes the transition from the roof into the upper portions of the central part of the pluton. The nature of the project required detailed mapping to address the question of whether stoping and assimilation of country rock have contributed significantly to the growth of the pluton. Thin sections of 22 samples were cut and mounted for examination of mineralogy, and particularly for evidence of open system disequilibrium related to assimilation (e.g., reaction of xenocrysts with magma and/or mineral breakdown reactions).

\section{Rock Units}

The rock units in the Heterogeneous zone of the Aztec Wash pluton are highly variable as noted above, and have been described in detail by previous workers (Koteas, 2005; Bleick 2006; Ericksen 2006). They are simplified here for the purposes of mapping. For more detailed descriptions of rock units, the reader may refer to these studies.

\section{Quartz Monzonite to Quartz Monzodiorite}

This rock unit comprises a compositionally and texturally heterogeneous group of rocks (Bleick, 2006; Ericksen, 2006) that can occur as either sheets or larger irregularly 
shaped masses. Where sheeted, thicknesses of $15 \mathrm{~cm}$ to three meters are observed. The more feldspar-rich monzonitic sheets typically form thin ( $\mathrm{cm}$ to $\mathrm{dm}$ ) septa between thicker ( $\mathrm{m}$ scale) mafic sheets. Textures range from fine- to coarse-grained and the rocks are mineralogically quite variable, containing differing proportions of plagioclase, $\mathrm{K}$ feldspar, biotite and hornblende; quartz is always in low abundance. Centimeter to decimeter-scale mafic enclaves are common in the monzonitic rocks and rapakivi texture is observed in some areas.

\section{Gabbro/Diorite}

Gabbros and diorites range from coarse- to fine-grained and consist mainly of hornblende, plagioclase, and clinopyroxene. Minor olivine and biotite occur sporadically. The gabbroic/dioritic rocks primarily occur in sheets interlayered with more felsic rocks and as mafic enclaves.

\section{Granite Dikes}

The granite dikes are fine-grained with sparse phenocrysts of plagioclase, quartz, K-feldspar, biotite and trace amounts of hornblende. Dikes differ in thickness from approximately one to as much as fifteen meters, strike north-south in general, and cut the all other units in the Aztec Wash pluton in the map area. Composite dikes composed of fine-grained granite with mafic (basaltic) pillows (see immediately below) and enclaves are a variant of this rock type. 


\section{Basaltic Dikes}

Fine- to medium-grained, basaltic porphyry dikes are primarily composed of hornblende, plagioclase clinopyroxene, and biotite. They are typically thinner than the fine-grained granite dikes and are between $30 \mathrm{~cm}$ to a meter in width, and like the granite dikes generally strike north-south in the map area.

\section{Ireteba Granite}

The Ireteba granite is a medium- to coarse-grained granite that contains conspicuous, 1-2 $\mathrm{cm}$ anhedral quartz phenocrysts. It also contains plagioclase, $\mathrm{K}$ feldspar, and biotite.

\section{Orthogneiss}

The orthogneiss is granoblastic to porphyroblastic, medium-to coarse-grained, black and white to gray and white-banded gneiss, with strong solid-state foliation. The protolith rock was primarily biotite-hornblende diorite to granodiorite and consists of plagioclase, biotite, hornblende, and quartz with minor K-feldspar. Foliation is defined by compositional layering of lighter-colored, coarse, plagioclase-rich layers alternating with finer-grained, darker bands of platy biotite and hornblende. The bands are several $\mathrm{mm}$ to $2-3 \mathrm{~cm}$ in width. Folding of gneissic bands occurs over a wavelength of $2 \mathrm{~cm}$ to several meters (in larger xenoliths). Lineations in the orthogneiss in the study area are rare. Quartz is commonly recrystallized, feldspars are plastically deformed, and biotite and hornblende crystals are rotated and define foliation. 


\section{Amphibolite}

Amphibolite xenoliths that are medium- to coarse-grained and composed primarily of hornblende and plagioclase are present locally in the map area. A weak foliation and lineation were observed in most outcrops. Thin sections showed growth of hornblende around cores of biotite, and recrystallized quartz and plagioclase.

\section{Granitic Leucogneiss}

Granitic leucogneiss is a coarse-grained rock with quartz, plagioclase, and Kfeldspar with minor biotite and/or hornblende (Color Index $<15$ and in some cases $<5$ ). Quartz is recrystallized showing bulging, porphyroclastic microstructure and with evidence for recrystallization and creep. Plagioclase exhibits brittle and ductile deformation, and recrystallization of smaller euhedral grains. Large feldspar grains are also partially recrystallized and commonly display irregular margins. Biotite and hornblende are recrystallized and segregated in bands between regions of quartz and plagioclase.

\section{Xenolith Distribution, Size, Contact Relationships, and Fabrics}

Xenoliths are restricted to the central portion of the pluton, and entirely within the Heterogeneous zone, as noted by Koteas (2005) in his mapping of the entire pluton (Fig.3). Xenoliths occur throughout the entire structural depth of the pluton but are laterally bounded by a narrow 10 and $30 \mathrm{~m}$ irregular, but generally east-west trending transition zone; in contrast, xenoliths are absent from the pluton to the north of the 
transition zone (Plate 1). The transition zone therefore cuts vertically across the "stratigraphy" of the pluton (Fig. 3).

South of this transition zone and within the map area, not only are xenoliths much more abundant, but very few sheeted sequences can be traced more than a few meters. The majority of mafic sheets in this area appear to be incoherent fragments with widely varying strikes (Plate 1) but otherwise are similar to sheeted sequences in other areas where sheet orientations are more consistent (e.g., Coiner, 2003; Ericksen, 2006). In the areas outside the xenolith-rich zones sheeted sequences are abundant, and individual sheets and/or sheet sequences are traceable for many tens to hundreds of meters both laterally and vertically (Coiner, 2003; Koteas, 2005; Bleick, 2005; Ericksen, 2006).

Representative sizes of xenoliths were recorded at each field station where available, and then grouped into one of five arbitrary size categories ranging from 1 centimeter to $>10$ meters in the longest dimension (Plate 2). The classes described above were aggregated into three groups to provide a more valid statistical comparison; with larger $\mathrm{N}$; small $(0.1 \mathrm{~cm}-1.0 \mathrm{~m})$; medium $(>1.0 \mathrm{~m}-6.0 \mathrm{~m})$; and large $(>6.0 \mathrm{~m})$.

The contact relationships between the xenoliths and surrounding host plutonic rock are of three types: sharp, gradational, and diffuse. Sharp contacts are characterized by a transition from xenolith margin to pluton of across a distance $\leq 2 \mathrm{~mm}$, and evidence for mechanical disaggregation of individual xenoliths into smaller xenolith fragments or xenocrysts is absent on an outcrop scale near the contact (Fig. 4). Gradational contacts include transitions from xenolith to pluton across a distance of $2 \mathrm{~mm}$ to $1 \mathrm{~cm}$ scale; in many cases, the plutonic and xenolith material interfinger within this thin contact. A small area of physical/mechanical mixing commonly parallels the margin of the xenolith 


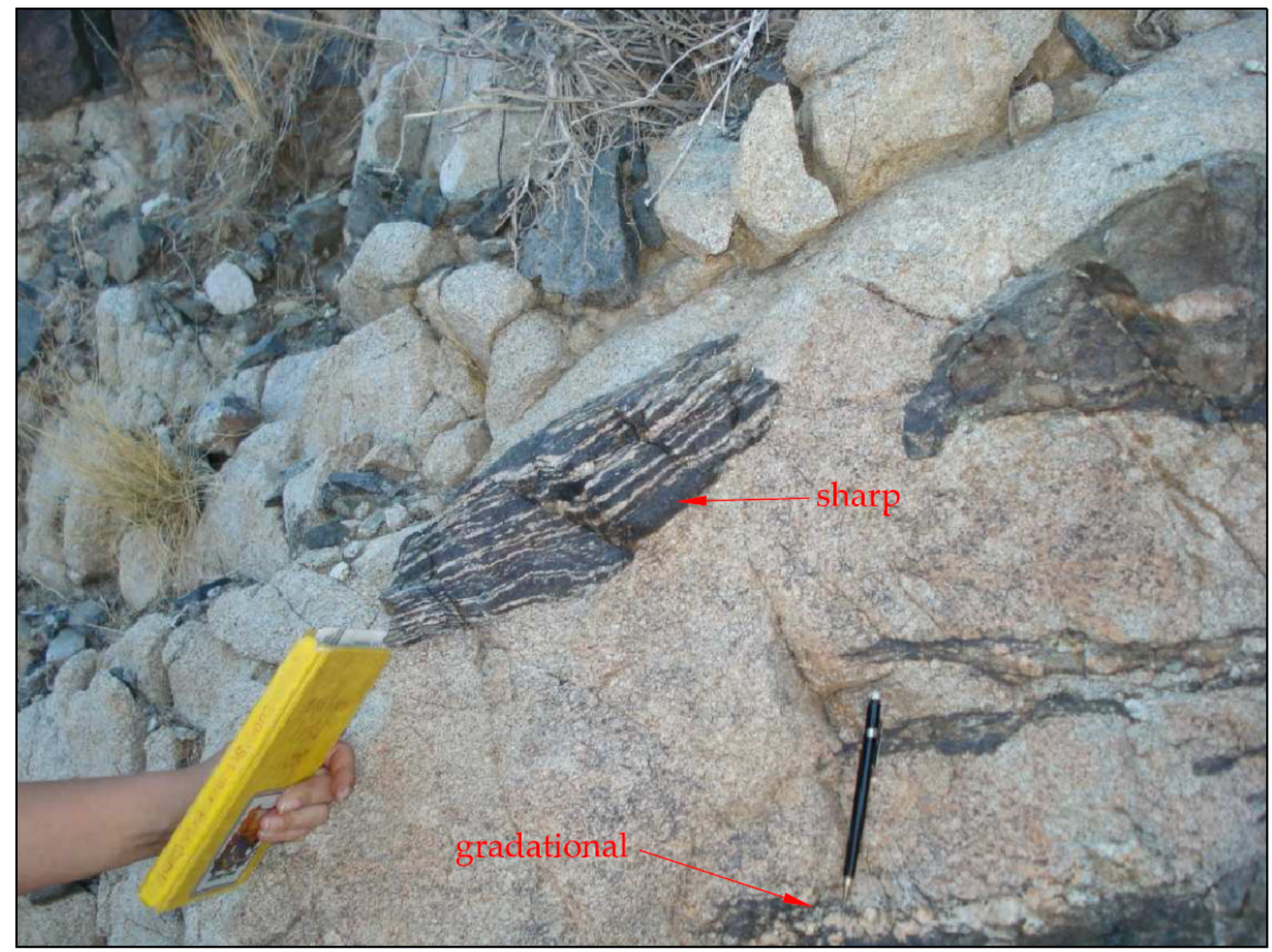

Figure 4. Sharp and gradational xenolith contact relationships. Example of xenoliths with differing margins, foliations, textures, and compositional variation surrounded by quartz monzonite. 
often forming ribbons or globular shapes (Figs. 5 and 6). Xenoliths with no discrete margins are considered to be diffuse. A diffuse transition of xenolith into pluton occurs over several centimeters, with no clear dividing line between xenolith and pluton but rather a zone that contains xenocrysts from the gneiss (Fig. 7).

Gradational xenolith margins displayed evidence of physical mixing of minerals from the xenoliths into the pluton. These include interfingering of pluton material and xenoliths, dismemberment, and ribboning of xenoliths, and local xenocrysts of plagioclase and/or K-feldspar (Fig. 6).

Several of the xenolith margins were also observed under a petrographic microscope. In thin section, large deformed quartz grains are commonly entrained in quartz monzonite. Bands of biotite were observed to extend from xenolith material into plutonic material. Larger feldspars that appeared to be derived from the margins of diffuse xenoliths were also observed. However, obvious reactions or feldspar dissolution were not observed in any thin sections collected, nor were reactions (i.e., biotite breakdown reactions) observed near contacts of gneisses.

The contact relationships of the xenoliths show no obvious relationship to the size of xenoliths, their vertical or lateral position within the pluton, the composition of the gneiss, or the composition of the plutonic material with which gneisses are in contact. Xenoliths with strongly contrasting margin characteristics commonly occur together on a scale of a meter or less (Figs. 4-7) at the same horizon.

Fabrics in the xenoliths were measured throughout the field area. Foliations were recorded and plotted on the map to examine whether the xenoliths maintained a 


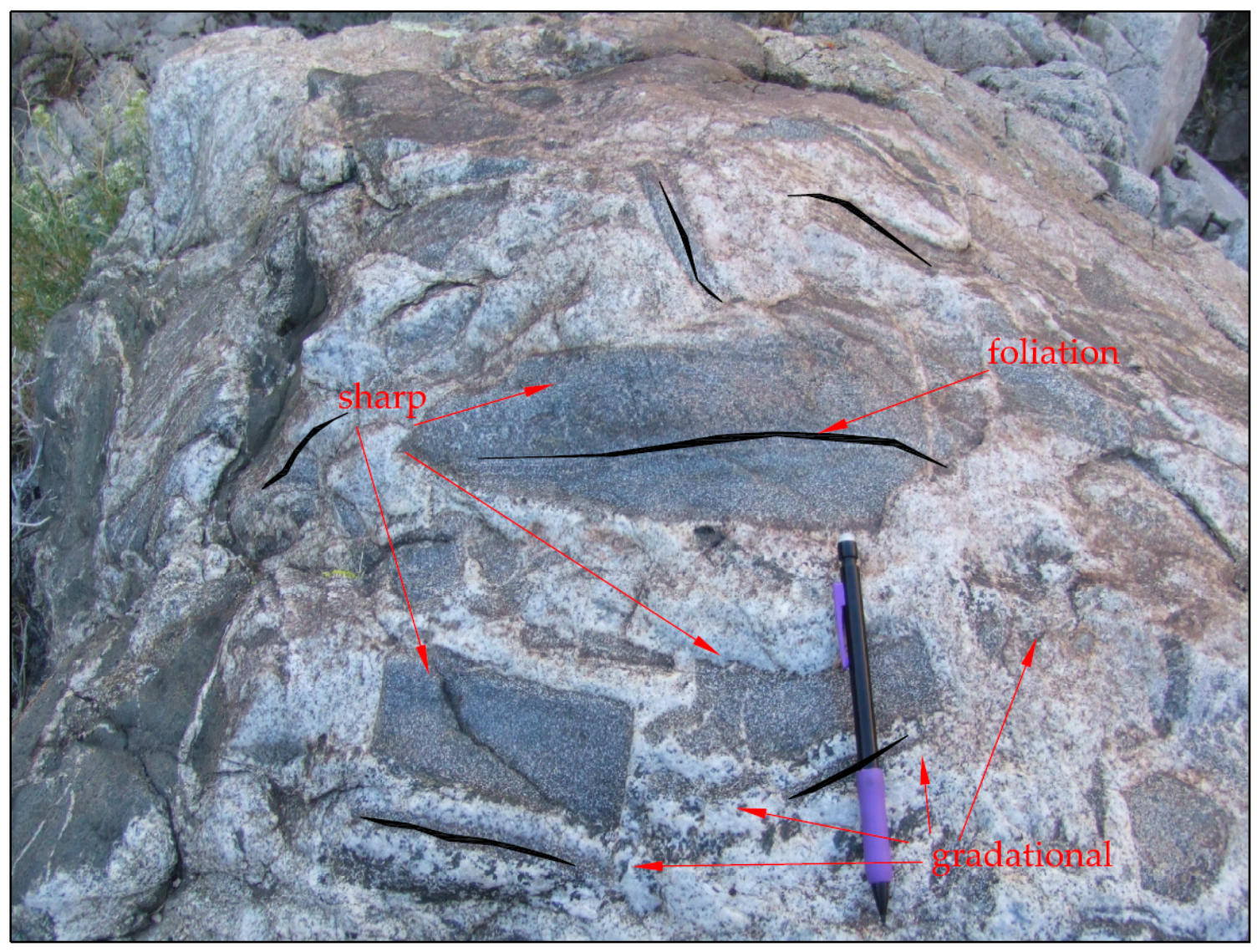

Figure 5. Variation in xenolith contact relationships. Closely spaced xenoliths show variable margin characteristics and inconsistent foliations. 


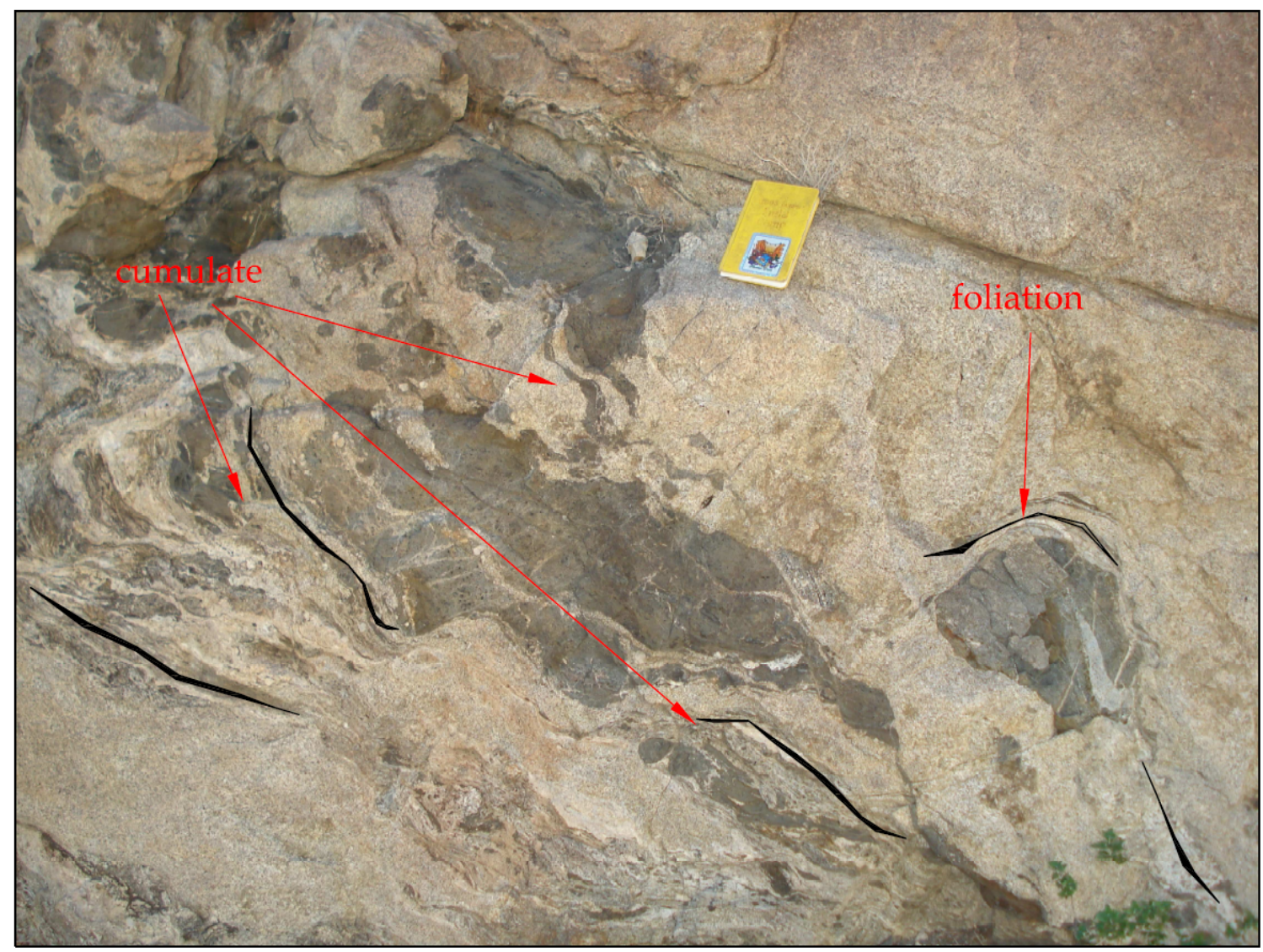

Figure 6. Xenolith contact relationships. Example of closely spaced xenolith fragments injected with quartz monzonite (cumulate) parallel to foliation plane forming wispy edges and mixing with quartz monzonite. 


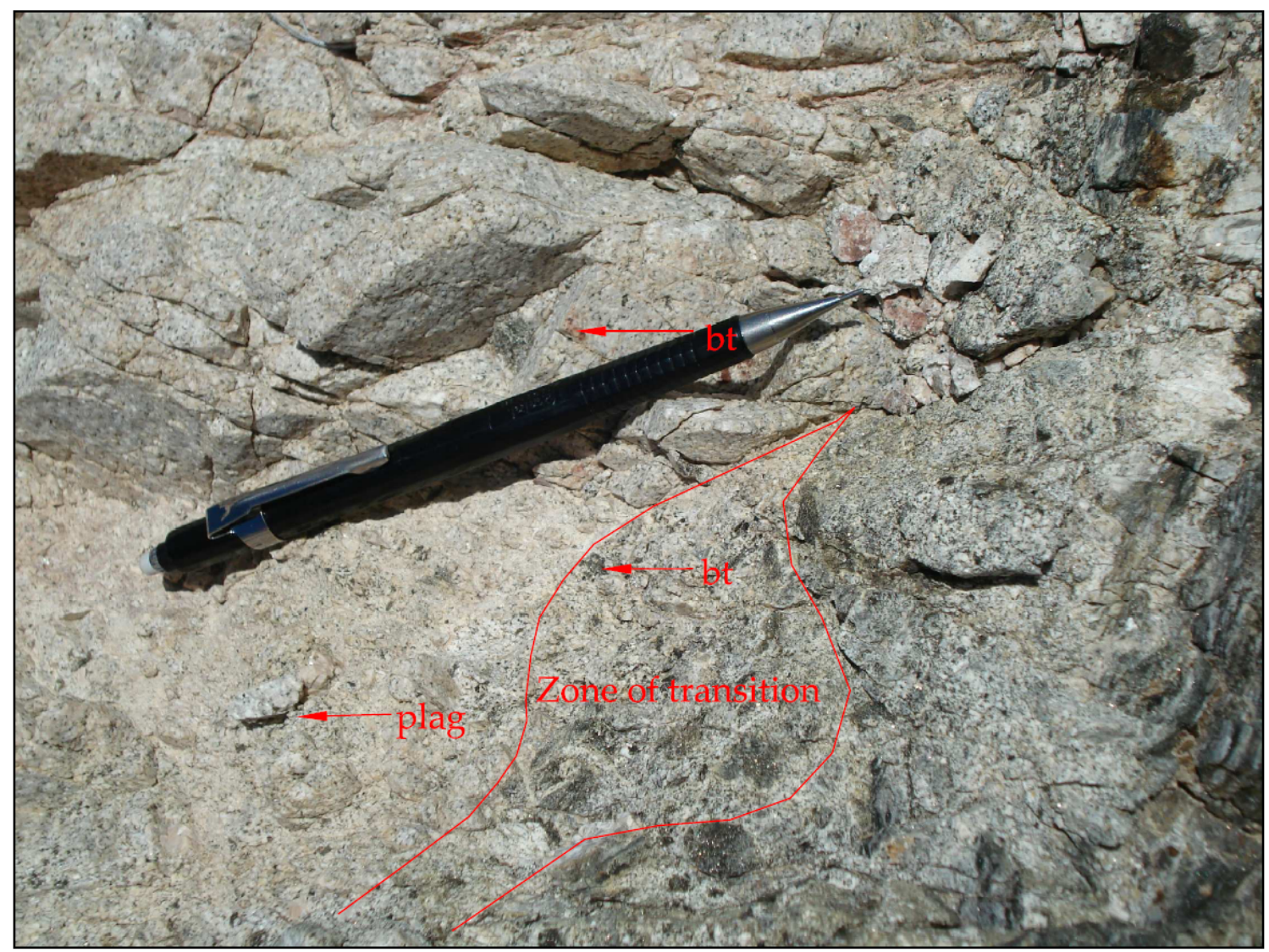

Figure 7. Xenocrysts in quartz monzonite. Biotite clusters and plagioclase xenocrysts observed in quartz monzonite adjacent to xenolith with a diffuse contact. 
consistent foliation and whether they followed regional foliations in surrounding host rocks. Foliation measurements were taken outside of the pluton from the closest roof exposures for comparison.

\section{Mafic and Silicic Sheeted Sequences and Granite Pipes}

Sheeted sequences encountered throughout the Aztec Wash pluton consist of medium to fine grained mafic (gabbro/diorite) sheets (Figs. 8-12) interlayered with coarse-grained quartz monzonites to monzonites. The monzonitic rocks form thin $(\mathrm{cm}$ to $\mathrm{dm}$ ) septa between thicker ( $\mathrm{dm}$ to $\mathrm{m}$ ) mafic sheets, and have been previously interpreted as feldspar-rich cumulates from which granite melt has been extracted (Patrick and Miller, 1997; Harper et al., 2004; Miller et al., 2005; Ericksen, 2006) (Fig. 8). In several outcrops there are circular to elliptical pipes, $5-10 \mathrm{~cm}$ in diameter, of fine-grained to medium-grained granite (Fig. 13) that emanate from the monzonitic layers and cut up through the mafic sheets. These are interpreted to form by vertical injection of felsic granite that is extracted by compaction from the mushy, crystal-rich pluton floor as new mafic sheets flow onto the floor and begin to settle and cool (Wiebe and Collins, 1998; Patrick and Miller, 1997) (Fig. 13). The long axis of the pipe therefore indicates the paleo-up direction, and can be used to determine the orientation of the pluton floor and thus the direction of gravity at the time of sheet emplacement (Fig. 14). Sheet orientations have until the present study only been measured in areas of the pluton well away from the xenolith-rich areas (Coiner, 2003; Koteas, 2005; Bleick, 2005; Ericksen, 2006). Based on these earlier studies, the sheeted sequences appear to provide excellent 

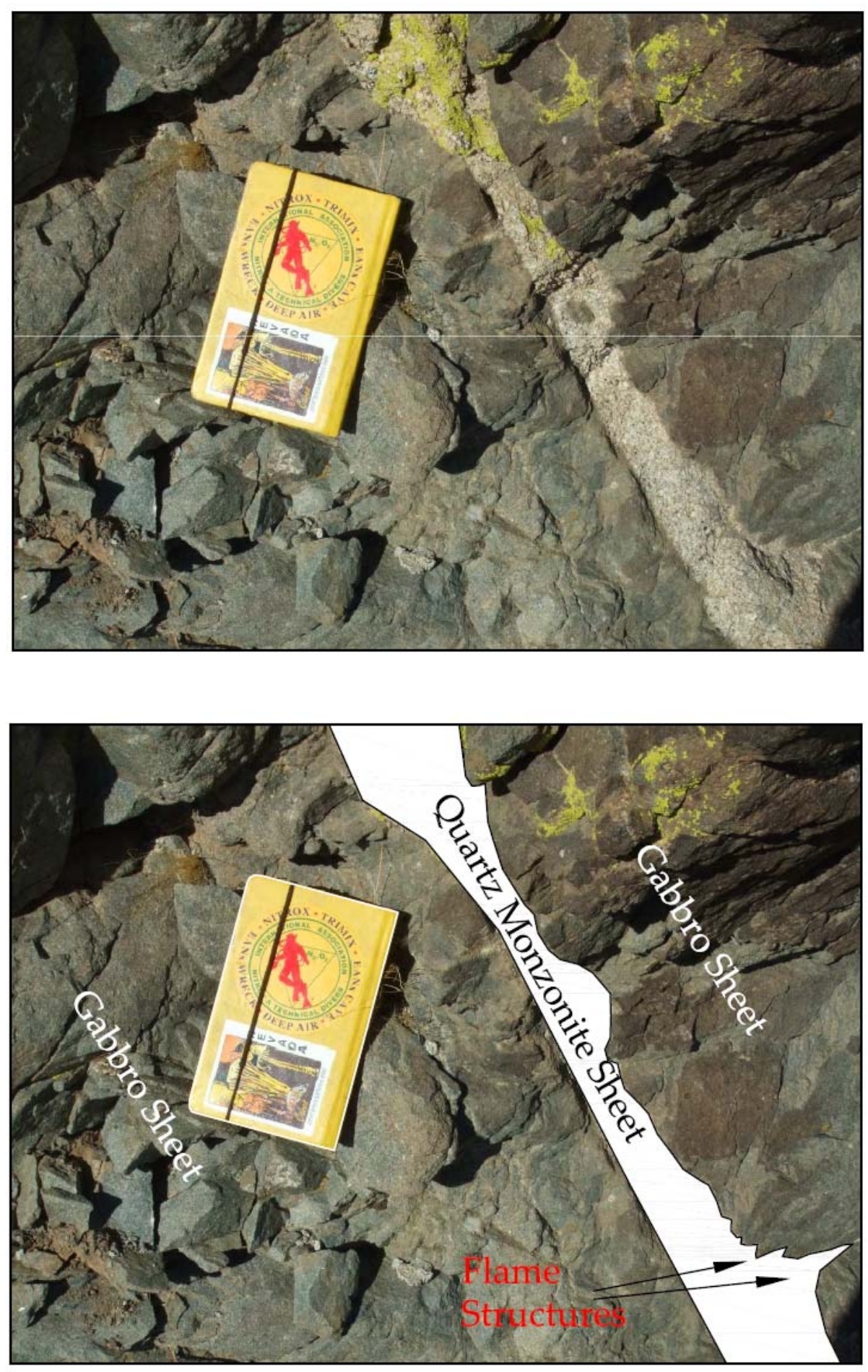

Figure 8. Mafic and silicic sheets. Sequences of layered fine grained gabbro and coarse grained quartz monzonite cumulate sheets within the study area. Flame structures indicate paleo-up direction at time of emplacement. 

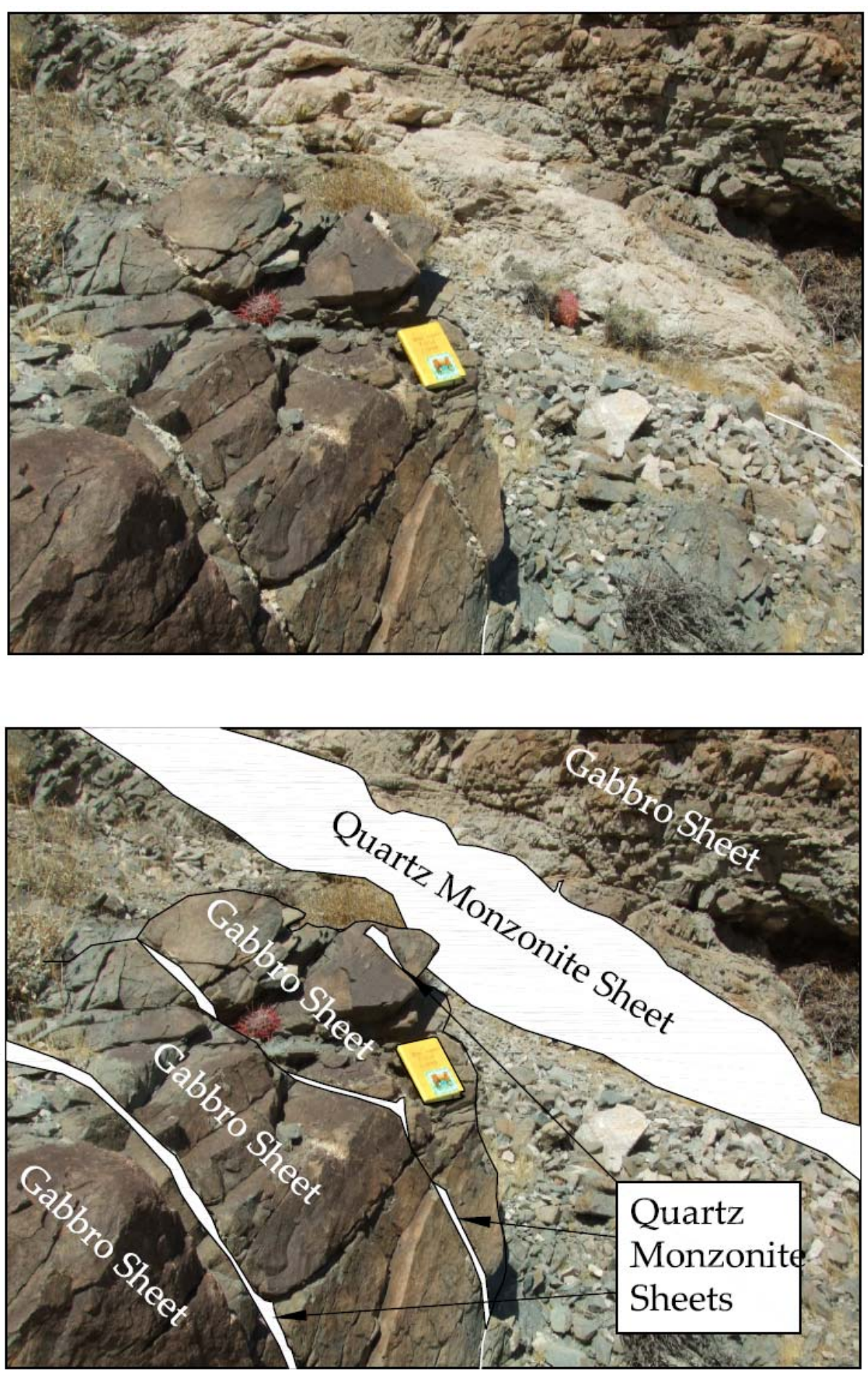

Figure 9. Mafic and silicic sheets. Additional example of sequences of layered fine grained gabbro and coarse grained quartz monzonite cumulate sheets within the study area. Sheets vary from $\mathrm{cm}$ to $\mathrm{m}$ in thickness. 


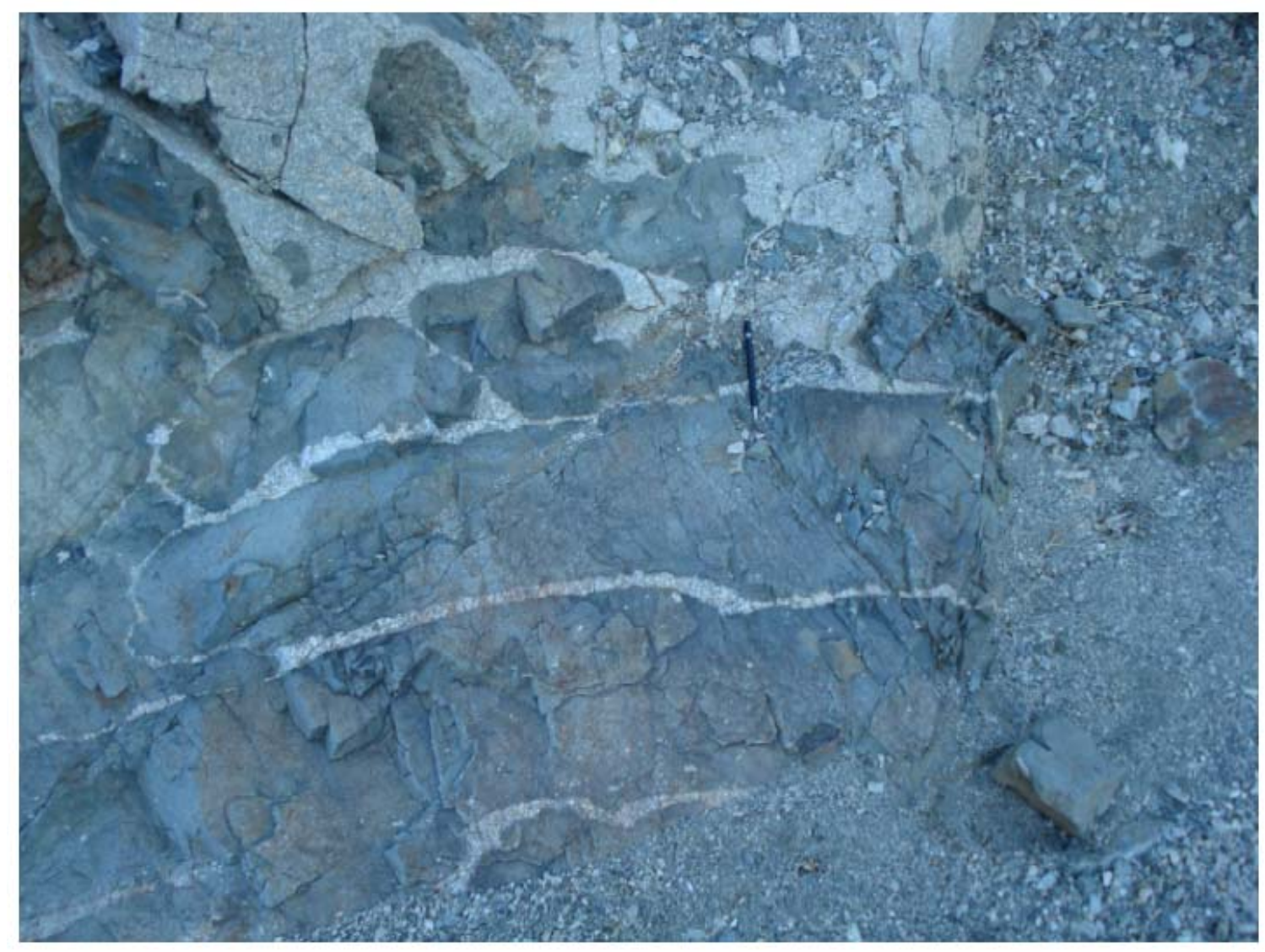

Figure 10. Flattened, oblate-ellipsoid enclaves in mafic sheet. 


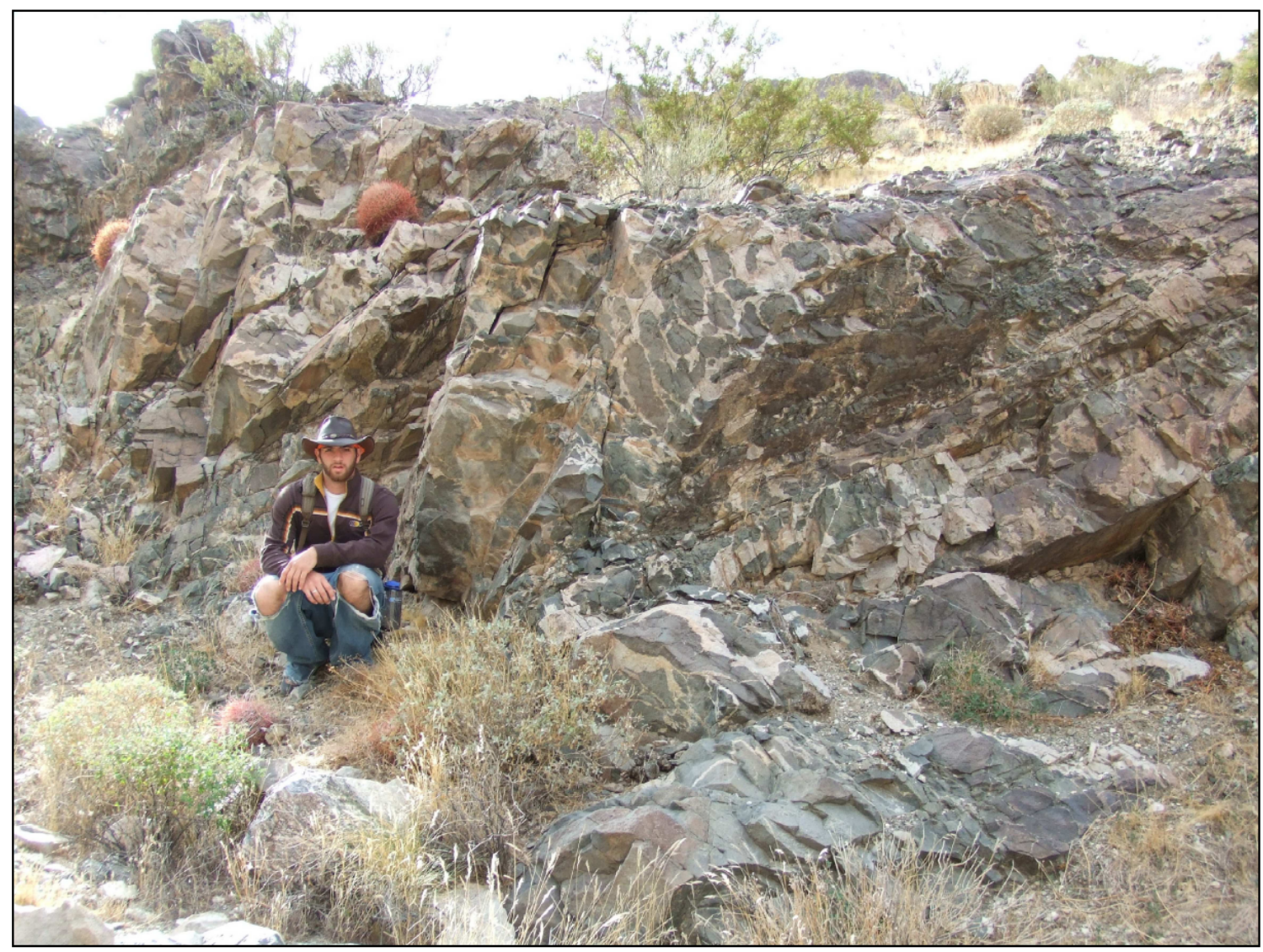

Figure 11. Mafic sheet rich in enclaves. Mafic sheet composed of abundant mafic enclaves. Outcrop is approximately $4 \mathrm{~m}$ in height. 


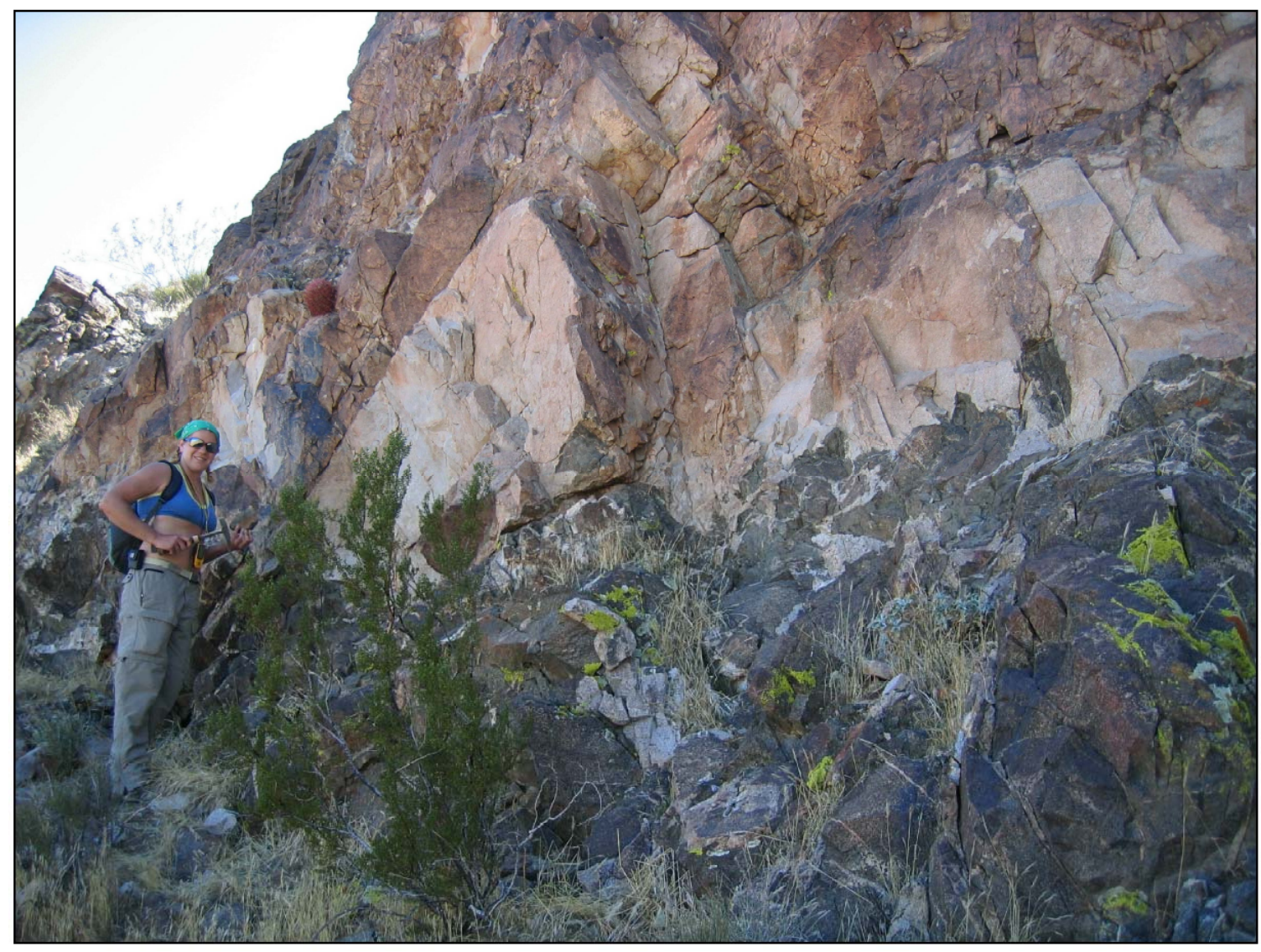

Figure 12. Contact between mafic and silicic sheet. 


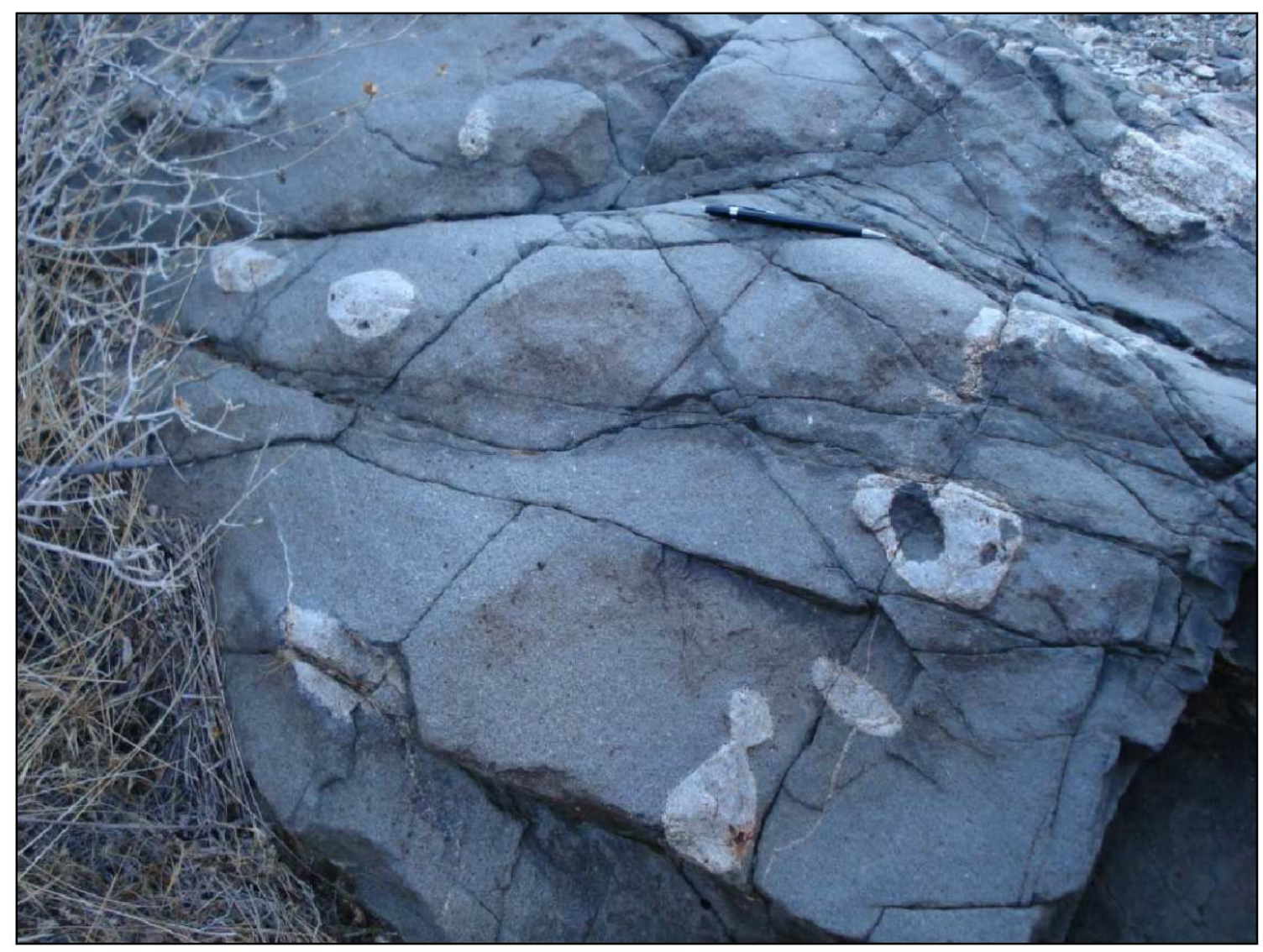

Figure 13. Granite pipes. Granite pipes in study area indicate paleo-up direction at time of emplacement. 

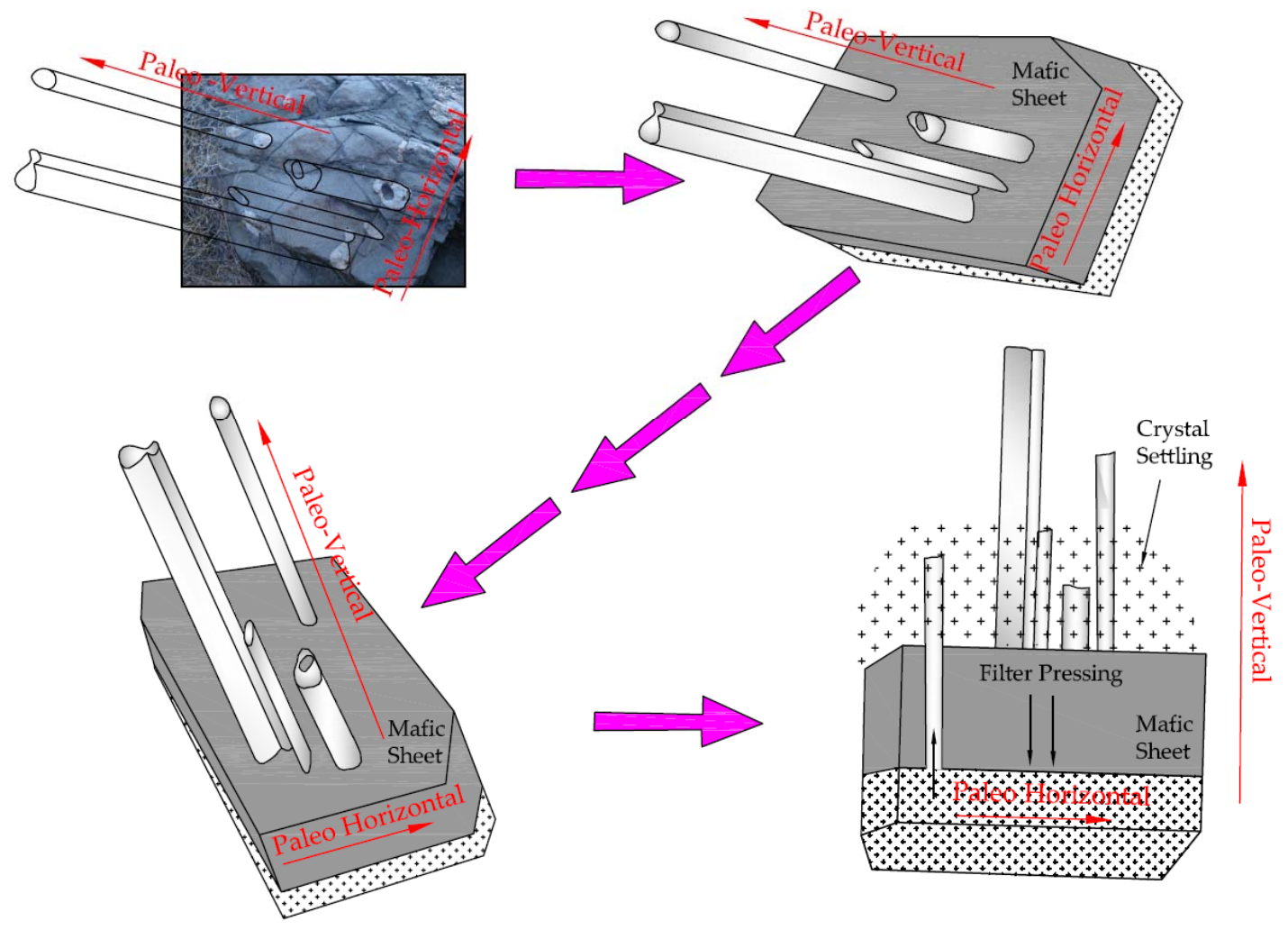

Figure 14. Generalized model of pipe formation. Schematic model of pipes rotated back to their original orientation, and a generalized illustration of how pipes form. Cross-hatched material represents granitic cumulate, dark gray hatch represents mafic sheet injections. 
controls on tilting of the pluton and strike consistently to the north-northwest and dip moderately $\left(\mathrm{ca} .50^{\circ}\right)$ to steeply east-northeast, and granite pipes plunge perpendicular to the sheet contacts (Coiner, 2003; Koteas, 2005; Ericksen, 2006) (Fig. 14). The granitic pipes that are found in the sheeted sequences provide a consistent paleo-vertical direction of pluton "up" to the east-northeast in areas of the Aztec Wash pluton east of the Pipe Canyon fault.

Where traceable, sheets were mapped and orientations were recorded. Field relationships between the sheeted sequences and the xenoliths are displayed on Plate 1. Granitic pipes, flattened enclaves within sheet sequences, load casts, and flame structures were recorded in the field for comparison with the data reported in earlier work from outside the xenolith-rich zone (Figs. 8, 10, and 13). This was done to evaluate whether tilt indicators in the xenolith-rich zone, where the mapping was done, gave the same general tilt and also to evaluate the degree of possible disruption of the sheeted sequences by movement of xenoliths.

\section{Geochemical Samples}

A representative set of 11 samples was collected for geochemical analysis to examine whether and to what degree xenoliths may have chemically interacted with Aztec Wash magmas during growth of the pluton. Samples were chosen to represent the range of xenolith compositions and textures, establish a baseline for uncontaminated Aztec Wash plutonic rock, and to identify any assimilates or hybrids between xenoliths and pluton. The latter samples were collected adjacent to xenoliths that appeared to 
display field evidence of disintegration and assimilation of xenoliths. These outcrops appeared to transition from typical Aztec Wash pluton to hybrids (?) with larger crystal sizes (xenocrysts?) and finally to intact xenoliths. The sample group includes several orthogneisses of variable color index, two amphibolites, Aztec Wash quartz monzonite that was well away from any xenolith contacts, and two Aztec Wash quartz monzonites that were judged to have been possibly contaminated, based on their proximity to disaggregated and dismembered xenoliths and apparent xenocrysts.

Fresh pieces of rock were crushed using standard crushing techniques to produce a homogeneous mixture of small (sub-cm) rock chips. These samples were sent for final milling and analysis for major and trace elements to the Geoanalytical Lab at the Washington State University. All geochemical analysis and methods used as well as an assessment of errors can be found at http://www.sees.wsu.edu/Geolab/note.html. 


\section{RESULTS}

\section{Host Rock and Xenolith Foliations}

Published regional structural data (Volborth, 1969; Faulds et.al, 2001) in the host rocks to the immediate north of the mapped portion of the Aztec Wash pluton are sparse but exhibit a moderately to steeply dipping and fairly consistent northwest-striking solid state foliation (biotite schistosity). To supplement these data, the host rock outcrops that are most proximal to the current study area were examined (Fig. 3). These outcrops occur at the structural roof of the Aztec Wash pluton.

In total, 330 foliations were measured in approximately 220 xenoliths within the Aztec Wash pluton study area. Lineations were observed only in one outcrop of amphibolite. In blocks where foliations varied, several orientations were taken. In some cases it was unclear whether the measurements were taken from a single large xenolith that had been broken apart locally or instead several smaller ones that had been brought together from disparate parts of the magma chamber. If adjacent xenoliths had similar composition and texture, they were recorded as multiple foliations of a single xenolith that had broken apart. Multiple measurements of individual blocks were also taken periodically to assure quality control of the measurements. Eleven foliation measurements from the most proximal (approximately $1000 \mathrm{~m}$ away) and structurally intact piece of host rock roof (Precambrian orthogneiss) above the Aztec Wash pluton were also recorded. 
Foliation measurements of xenoliths within the study area of the Aztec Wash pluton yield a "scatter"-plot of nearly random orientations (Plate 1, Fig. 15). No clearly dominant orientation is observed in the xenoliths, but a very broad maximum of poles to foliation on a lower hemisphere sterographic projection, corresponding to moderately to gently dipping and northwest-striking fabrics is observed (Figs. 15-17). Nevertheless, the simple plot of poles (Figs. 15 and 16) serves to illustrate the highly variable nature of xenolith foliations with respect to each other. In contrast, the 11 foliations from the closest intact piece of roof have very consistent northwest-striking, steeply dipping foliations (Figs. 17). Although this constitutes a relatively small number of measurements, the data are nevertheless consistent with published regional trends in Precambrian host rocks nearby (i.e. northwest-striking and steeply dipping). The published regional foliation data in the gneiss closest to the pluton (Volborth, 1973) and measurements taken from the closest exposures of host rocks at the roof of the pluton (Figs. 3 and 17) demonstrate a dominant northwest/southeast and moderate to steep ( $45^{\circ}$ $70^{\circ}$ ) orientation in the gneiss. To the west and north foliations trend more east-west but are consistent over large areas.

Foliations within the xenoliths thus occur at widely varying angles to regional host rock foliations. Xenolith foliations also are observed at highly variable angles with respect to sheet contacts (Fig. 18) and to each other, often in adjacent xenoliths (Figs. 15 and 18). The structural data also show no evidence of obvious folding, given that there is no fold girdle apparent in the data. Mineral foliations in the quartz monzonite are sparse but steeply-dipping and northwest-striking (Fig. 19). 


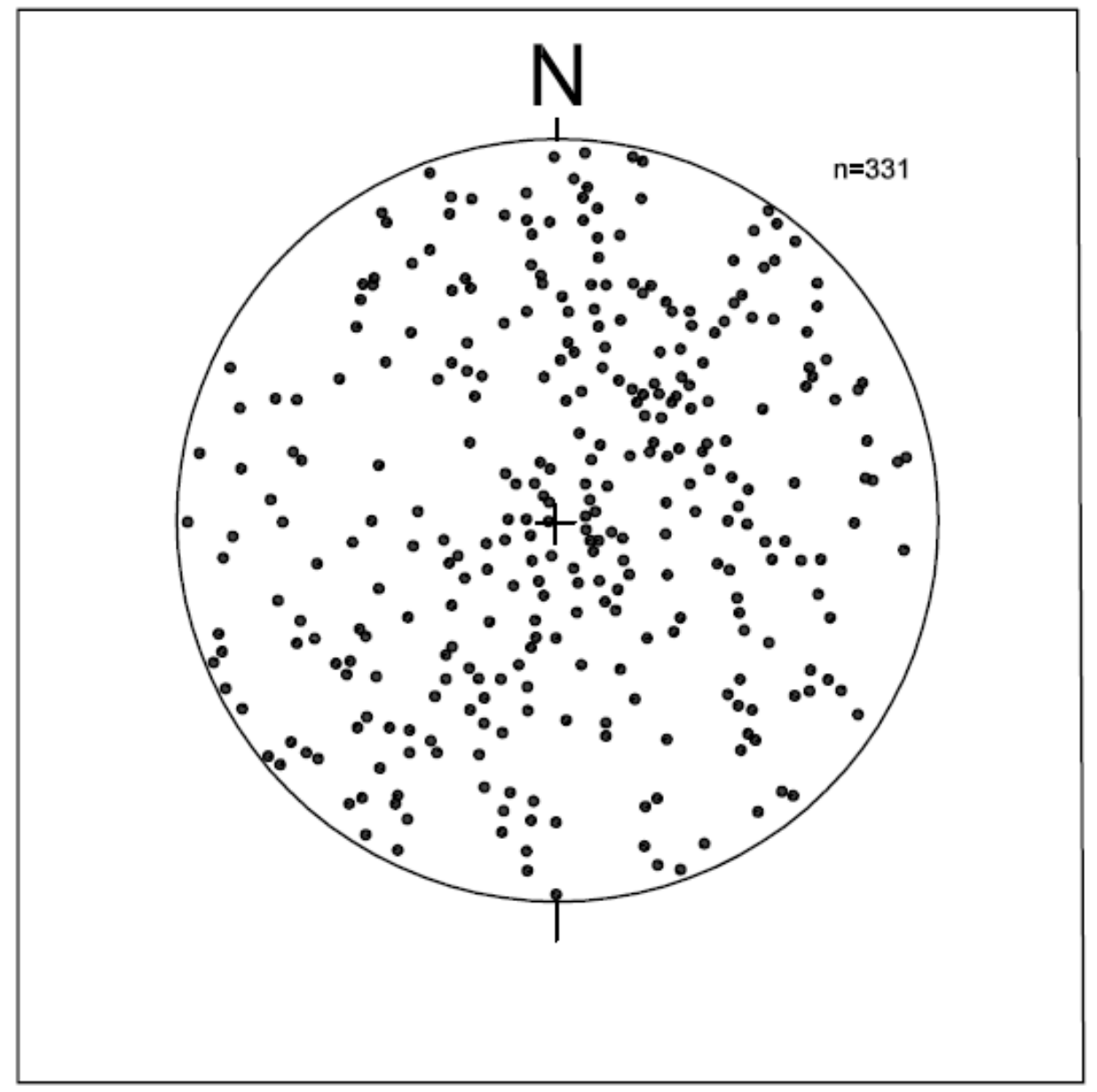

Figure 15. Stereographic projection of poles to xenolith foliations. All poles are lower hemisphere projections for this and subsequent plots. 


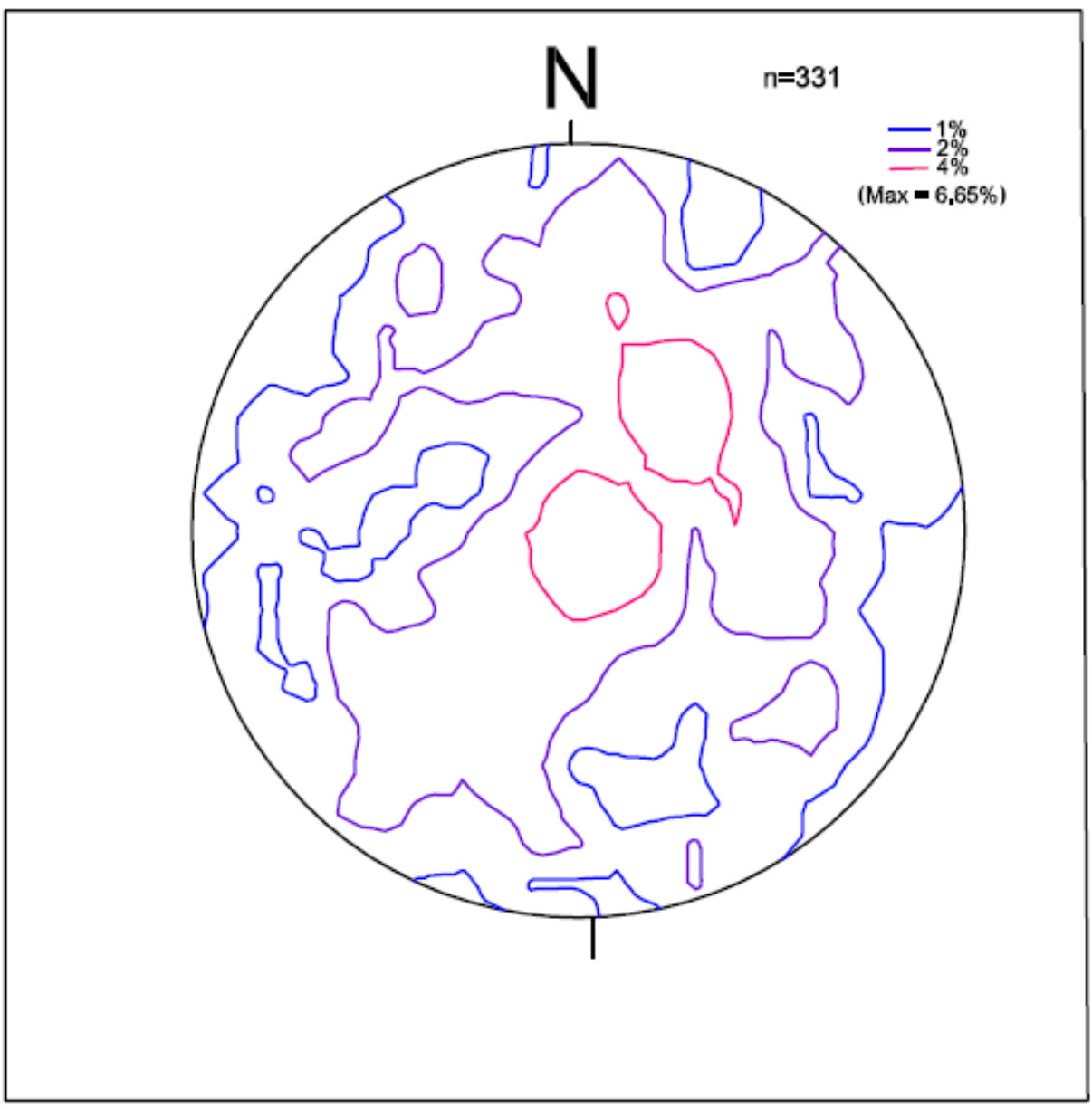

Figure 16. Contoured sterographic projection of poles to xenoliths. Contour interval is $2.0 \sigma$ following the method of Kamb (1959), which is used in all subsequent plots with contours. 


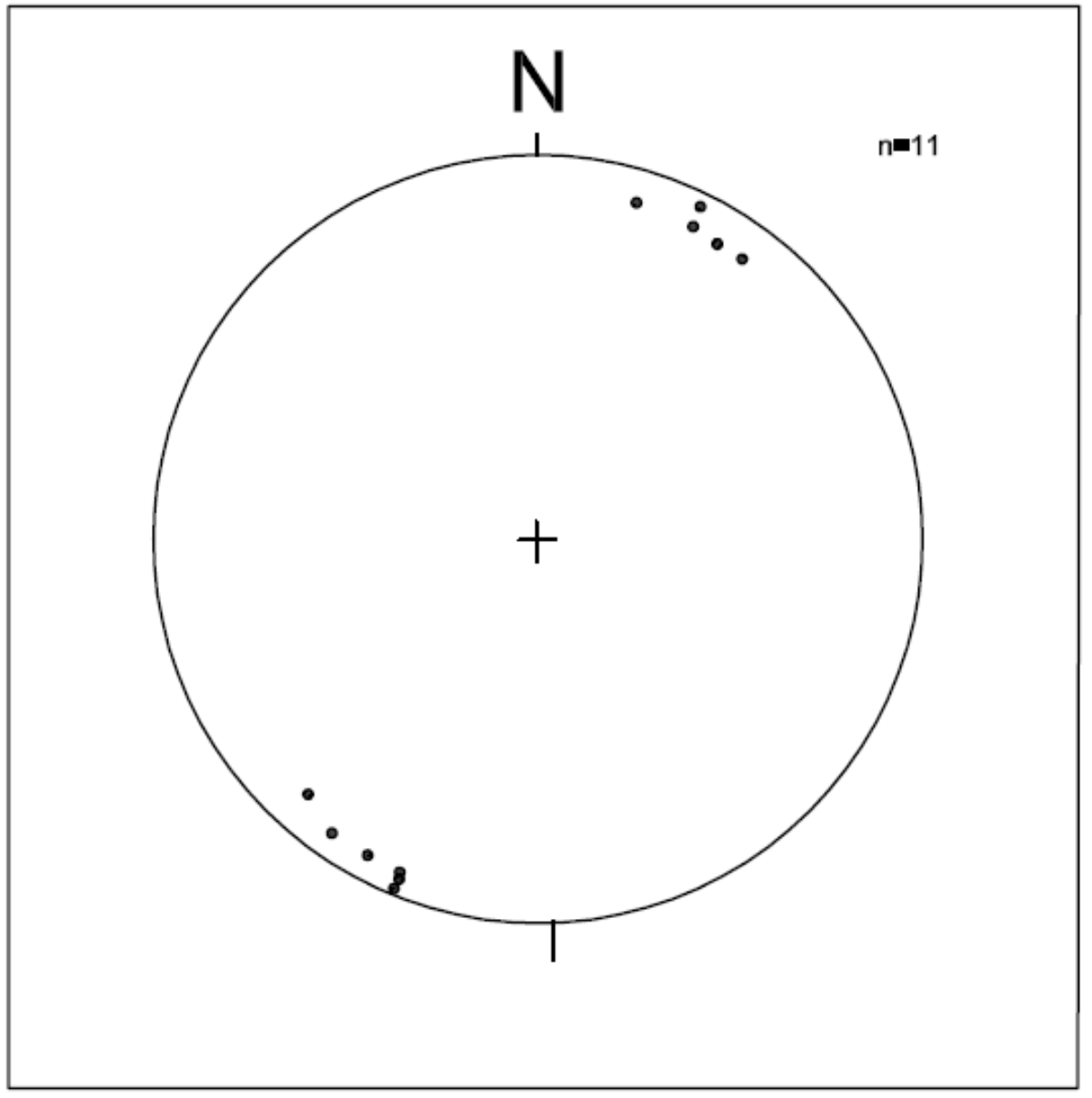

Figure 17. Stereographic projection of poles to host rock foliations. Foliations of Precambrian host rock are locally consistent and have an average dip angle is $78^{\circ}$. 


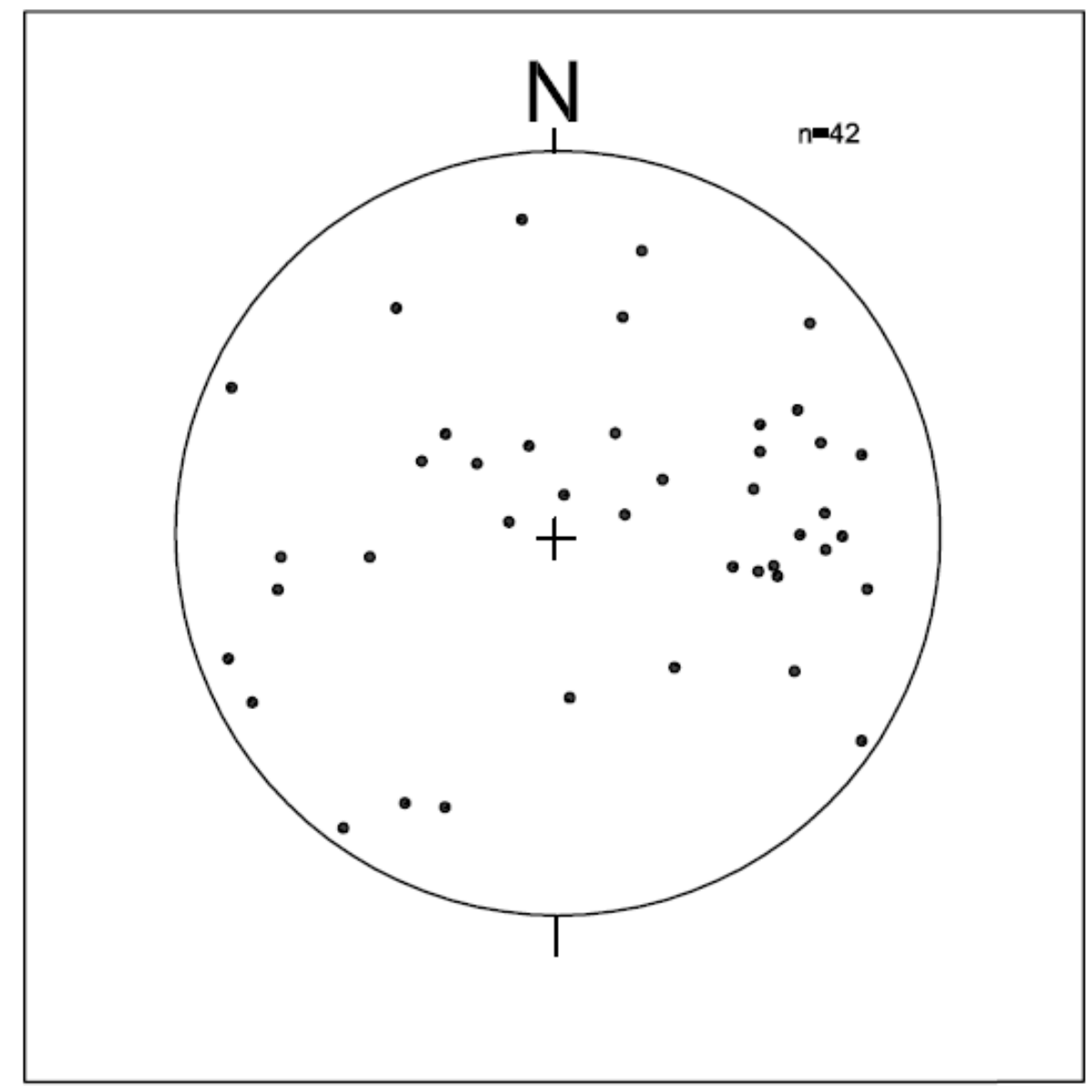

Figure 18. Stereographic projection of poles to sheet orientations. 


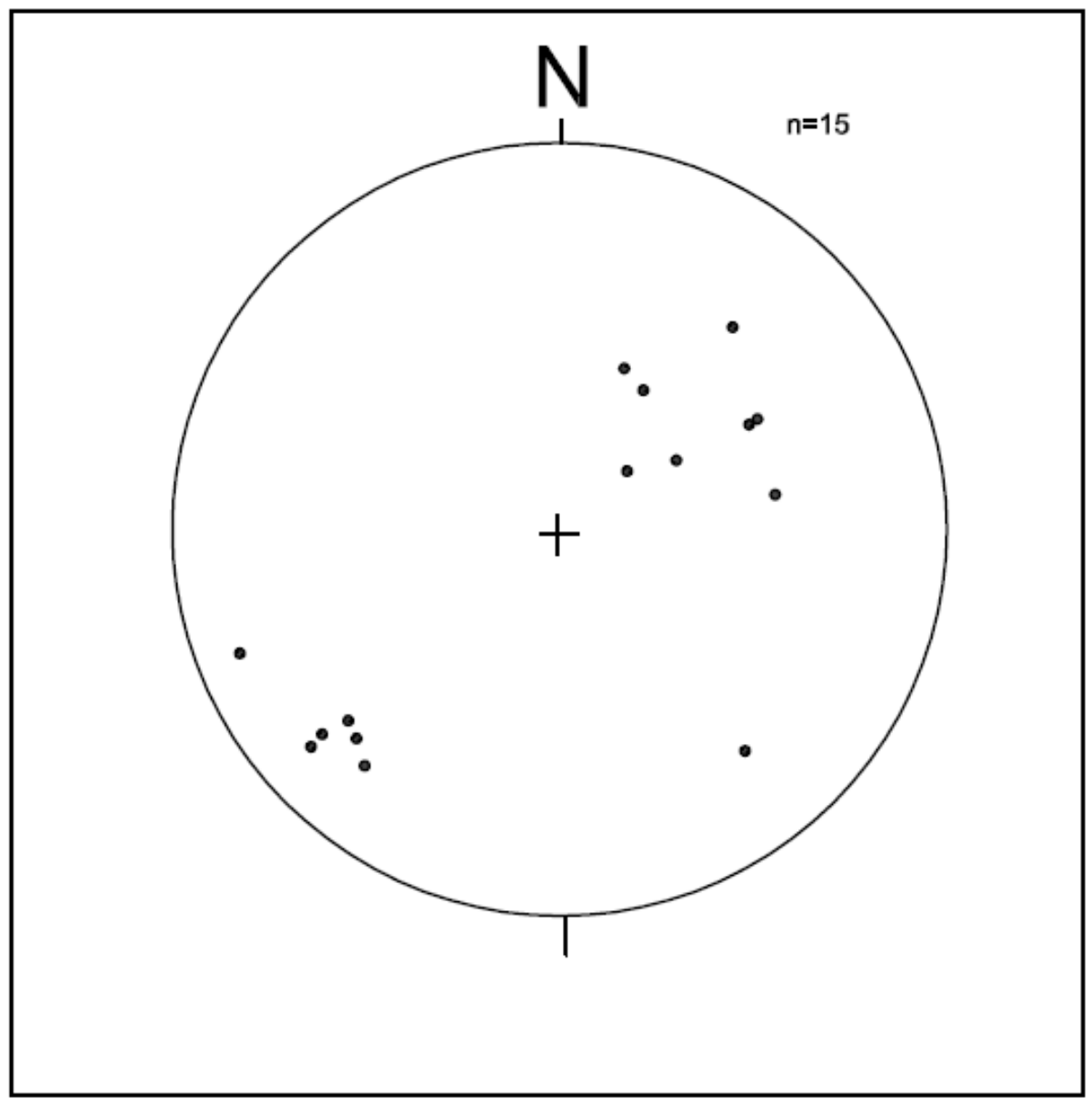

Figure 19. Stereographic projection of poles to magmatic foliations. 


\section{Paleo-vertical Indicators}

Pipes, composed of coarse-grained quartz monzonite, were observed in several locations within the field area. They are concentrated most strongly in the margin between the xenolith-rich and xenolith-poor zone of the Aztec Wash pluton, where xenoliths are few and mafic and felsic sheets are abundant and are relatively coherent and traceable for an appreciable $(>50 \mathrm{~m})$ distance along strike. The pipe orientations (typically $45-65^{\circ}$ plunge) collected in the field support previous data that indicate paleoup to the northeast. Gravity-induced settling of sheet sequences was also observed in the field and is consistent with paleo-up to the northeast (Figs. 7, 12). Some enclaves within mafic sheets are consistent with flattening perpendicular to sheet contacts (Fig. 9).

\section{Geochemistry}

Selected major and trace elements (Table 1) are plotted versus $\mathrm{SiO}_{2}$ in Figures 20 to 23. The amphibolites and low silica (dioritic) gneisses bound the low end and the granitic gneisses (leuco-gneisses) bound the high end of the data arrays but show appreciable scatter for all elements. Samples of the quartz monzonite from adjacent to the xenoliths and compositionally and texturally similar rocks from Ericksen (2006), that are more than $1 \mathrm{~km}$ from any outcrops of host rocks or xenoliths, have $\mathrm{SiO}_{2}$ values between the gneiss compositions. Samples near the xenoliths have major and trace element concentrations that are very similar to Aztec Wash quartz monzonites in xenolith-free areas. With the exception of one compositional outlier identified as a 
Table 1. Whole rock geochemical data

\begin{tabular}{|c|c|c|c|c|c|c|}
\hline & $\begin{array}{c}\text { JNS191 } \\
\text { amphibolite }\end{array}$ & $\begin{array}{c}\text { JNS } 76-2 \\
\text { amphibolite }\end{array}$ & $\begin{array}{l}\text { JNS 139-1 } \\
\text { gneiss } \\
\end{array}$ & $\begin{array}{c}\text { JNS 174-5 } \\
\text { gneiss }\end{array}$ & $\begin{array}{c}\text { JNS 174-2 } \\
\text { gneiss }\end{array}$ & $\begin{array}{c}\text { JNS } 198 \\
\text { gneiss } \\
\end{array}$ \\
\hline $\mathrm{SiO}_{2}$ & 54.67 & 57.64 & 57.91 & 60.11 & 69.16 & 75.50 \\
\hline $\mathrm{TiO}_{2}$ & 1.136 & 1.277 & 1.338 & 1.293 & 0.889 & 0.025 \\
\hline $\mathrm{Al}_{2} \mathrm{O}_{3}$ & 20.64 & 13.59 & 19.37 & 18.25 & 14.24 & 13.66 \\
\hline $\mathrm{FeO}^{*}$ & 9.75 & 6.88 & 7.37 & 10.36 & 7.01 & 1.02 \\
\hline MnO & 0.190 & 0.151 & 0.174 & 0.169 & 0.119 & 0.044 \\
\hline MgO & 3.32 & 7.60 & 2.46 & 3.11 & 2.16 & 0.24 \\
\hline $\mathrm{CaO}$ & 2.80 & 6.68 & 4.31 & 0.66 & 1.3 & 1.61 \\
\hline $\mathrm{Na}_{2} \mathrm{O}$ & 3.82 & 3.28 & 4.65 & 0.90 & 1.74 & 2.70 \\
\hline $\mathrm{K}_{2} \mathrm{O}$ & 3.59 & 2.53 & 2.38 & 5.08 & 3.31 & 5.15 \\
\hline $\mathbf{P}_{2} \mathbf{O}_{5}$ & 0.081 & 0.364 & 0.040 & 0.060 & 0.056 & 0.049 \\
\hline \#sum & 96.48 & 97.57 & 97.83 & 96.21 & 96.29 & 97.60 \\
\hline $\mathrm{Ni}$ & 33 & 151 & 27 & 34 & 28 & 0 \\
\hline $\mathrm{Cr}$ & 111 & 414 & 64 & 157 & 102 & 4 \\
\hline $\mathbf{V}$ & 152 & 149 & 173 & 143 & 103 & 11 \\
\hline Sc & 27.1 & 20.4 & 24.3 & 27.4 & 17.8 & 7.5 \\
\hline $\mathrm{Nb}$ & 19.70 & 24.0 & 25.4 & 23.1 & 16.1 & 0.2 \\
\hline $\mathrm{Ta}$ & 0.98 & 1.79 & 1.33 & 1.52 & 0.99 & 0.12 \\
\hline $\mathbf{Y}$ & 54.60 & 23 & 32 & 62 & 48 & 40 \\
\hline $\mathrm{Zr}$ & 321 & 198 & 260 & 342 & 353 & 38 \\
\hline $\mathrm{Hf}$ & 9.12 & 5.49 & 7.41 & 9.92 & 10.09 & 1.25 \\
\hline $\mathbf{R b}$ & 240.5 & 70 & 133 & 193 & 124 & 129 \\
\hline $\mathrm{Sr}$ & 300 & 479 & 349 & 124 & 197 & 308 \\
\hline $\mathrm{Ba}$ & 782 & 627 & 402 & 1297 & 845 & 1049 \\
\hline Cs & 8.61 & 1.35 & 3.30 & 6.38 & 4.43 & 1.53 \\
\hline La & 60.81 & 58 & 64 & 54 & 55 & 27 \\
\hline $\mathrm{Ce}$ & 114.06 & 119.76 & 120.94 & 98.23 & 116.76 & 41.11 \\
\hline $\operatorname{Pr}$ & 12.85 & 12.86 & 12.98 & 11.38 & 13.60 & 3.80 \\
\hline Nd & 45.84 & 42.53 & 44.09 & 41.87 & 49.95 & 11.46 \\
\hline Sm & 8.68 & 7.54 & 6.85 & 8.45 & 9.48 & 1.92 \\
\hline $\mathrm{Eu}$ & 2.23 & 1.98 & 1.85 & 1.58 & 1.70 & 2.25 \\
\hline Gd & 8.85 & 6.00 & 5.14 & 9.62 & 8.72 & 2.11 \\
\hline $\mathrm{Tb}$ & 1.60 & 0.85 & 0.79 & 1.87 & 1.48 & 0.53 \\
\hline Dy & 10.33 & 4.77 & 5.30 & 12.29 & 9.09 & 5.03 \\
\hline Ho & 2.13 & 0.91 & 1.23 & 2.53 & 1.92 & 1.56 \\
\hline Er & 5.58 & 2.38 & 3.80 & 6.71 & 5.39 & 5.74 \\
\hline $\mathrm{Tm}$ & 0.83 & 0.35 & 0.63 & 0.97 & 0.80 & 1.08 \\
\hline $\mathrm{Yb}$ & 5.06 & 2.13 & 4.29 & 5.90 & 5.07 & 7.93 \\
\hline Lu & 0.80 & 0.33 & 0.70 & 0.90 & 0.79 & 1.34 \\
\hline Th & 13.94 & 10.70 & 20.40 & 18.80 & 20.12 & 2.00 \\
\hline $\mathbf{U}$ & 2.45 & 2.01 & 2.76 & 1.87 & 1.87 & 0.84 \\
\hline $\mathrm{Pb}$ & 24.34 & 11.70 & 35.07 & 11.71 & 17.89 & 64.40 \\
\hline
\end{tabular}

Note: Major element oxide concentrations in wt.\% are reported on a volatile-free basis.

* = Total $\mathrm{Fe}$ as FeO. \# = Original analyical sumsMajor elements and Ni, Cr, V determined by XRF. All other trace elements determined by ICP-MS. All trace elements in ppm. 
Table 1. Continued

\begin{tabular}{|c|c|c|c|c|}
\hline & $\begin{array}{c}\text { JNS 208-4 } \\
\text { AWH }\end{array}$ & $\begin{array}{c}\text { JNS 208-3 } \\
\text { AWH }\end{array}$ & $\begin{array}{c}\text { JNS 172-2 } \\
\text { AWH }\end{array}$ & $\begin{array}{c}\text { JNS } 169 \\
\text { AW }\end{array}$ \\
\hline $\mathrm{SiO}_{2}$ & 61.59 & 62.91 & 65.98 & 71.85 \\
\hline f $\mathrm{TiO}_{2}$ & 0.847 & 0.765 & 0.623 & 0.591 \\
\hline $\mathrm{Al}_{2} \mathrm{O}_{3}$ & 18.44 & 18.33 & 17.05 & 14.48 \\
\hline $\mathrm{FeO} *$ & 4.38 & 4.2 & 3.20 & 3.17 \\
\hline $\mathrm{MnO}$ & 0.072 & 0.076 & 0.057 & 0.085 \\
\hline MgO & 1.61 & 1.97 & 1.25 & 1.32 \\
\hline $\mathrm{CaO}$ & 3.37 & 4.15 & 2.77 & 2.63 \\
\hline $\mathrm{Na}_{2} \mathrm{O}$ & 3.97 & 4.31 & 4.21 & 4.36 \\
\hline $\mathrm{K}_{2} \mathrm{O}$ & 5.43 & 2.97 & 4.63 & 1.47 \\
\hline $\mathrm{P}_{2} \mathrm{O}_{5}$ & 0.281 & 0.270 & 0.224 & 0.045 \\
\hline \#sum & 97.39 & 97.01 & 97.10 & 97.63 \\
\hline $\mathrm{Ni}$ & 9 & 19 & 8 & 18 \\
\hline $\mathrm{Cr}$ & 19 & 33 & 14 & 70 \\
\hline v & 72 & 73 & 48 & 58 \\
\hline Sc & 11.5 & 8.1 & 5.7 & 9.8 \\
\hline $\mathrm{Nb}$ & 28.6 & 12.0 & 22.1 & 13.7 \\
\hline $\mathrm{Ta}$ & 2.74 & 0.70 & 1.90 & 1.30 \\
\hline$Y$ & 73 & 22 & 30 & 28 \\
\hline $\mathrm{Zr}$ & 557 & 357 & 324 & 245 \\
\hline $\mathrm{Hf}$ & 13.46 & 8.47 & 8.51 & 7.29 \\
\hline $\mathbf{R b}$ & 114 & 83 & 99 & 69 \\
\hline $\mathrm{Sr}$ & 759 & 810 & 647 & 297 \\
\hline $\mathrm{Ba}$ & 2414 & 2057 & 1507 & 221 \\
\hline Cs & 1.51 & 1.37 & 1.31 & 1.61 \\
\hline La & 126 & 75 & 79 & 64 \\
\hline $\mathrm{Ce}$ & 301.32 & 144.65 & 160.20 & 121.40 \\
\hline $\operatorname{Pr}$ & 37.41 & 16.16 & 17.67 & 13.50 \\
\hline Nd & 134.52 & 56.23 & 59.32 & 47.48 \\
\hline Sm & 25.14 & 9.39 & 10.00 & 7.86 \\
\hline Eu & 3.38 & 2.15 & 2.04 & 1.20 \\
\hline Gd & 18.38 & 6.85 & 7.23 & 5.74 \\
\hline $\mathrm{Tb}$ & 2.86 & 0.94 & 1.05 & 0.86 \\
\hline Dy & 16.36 & 5.06 & 5.86 & 5.12 \\
\hline Ho & 3.03 & 0.93 & 1.15 & 1.07 \\
\hline $\mathrm{Er}$ & 7.71 & 2.36 & 3.06 & 3.06 \\
\hline $\mathrm{Tm}$ & 1.06 & 0.33 & 0.45 & 0.47 \\
\hline $\mathrm{Yb}$ & 5.85 & 2.19 & 2.68 & 3.13 \\
\hline Lu & 0.79 & 0.37 & 0.41 & 0.50 \\
\hline Th & 21.18 & 10.18 & 19.36 & 20.02 \\
\hline $\mathbf{U}$ & 2.47 & 1.25 & 2.41 & 2.19 \\
\hline $\mathrm{Pb}$ & 52.38 & 33.61 & 23.74 & 20.47 \\
\hline
\end{tabular}



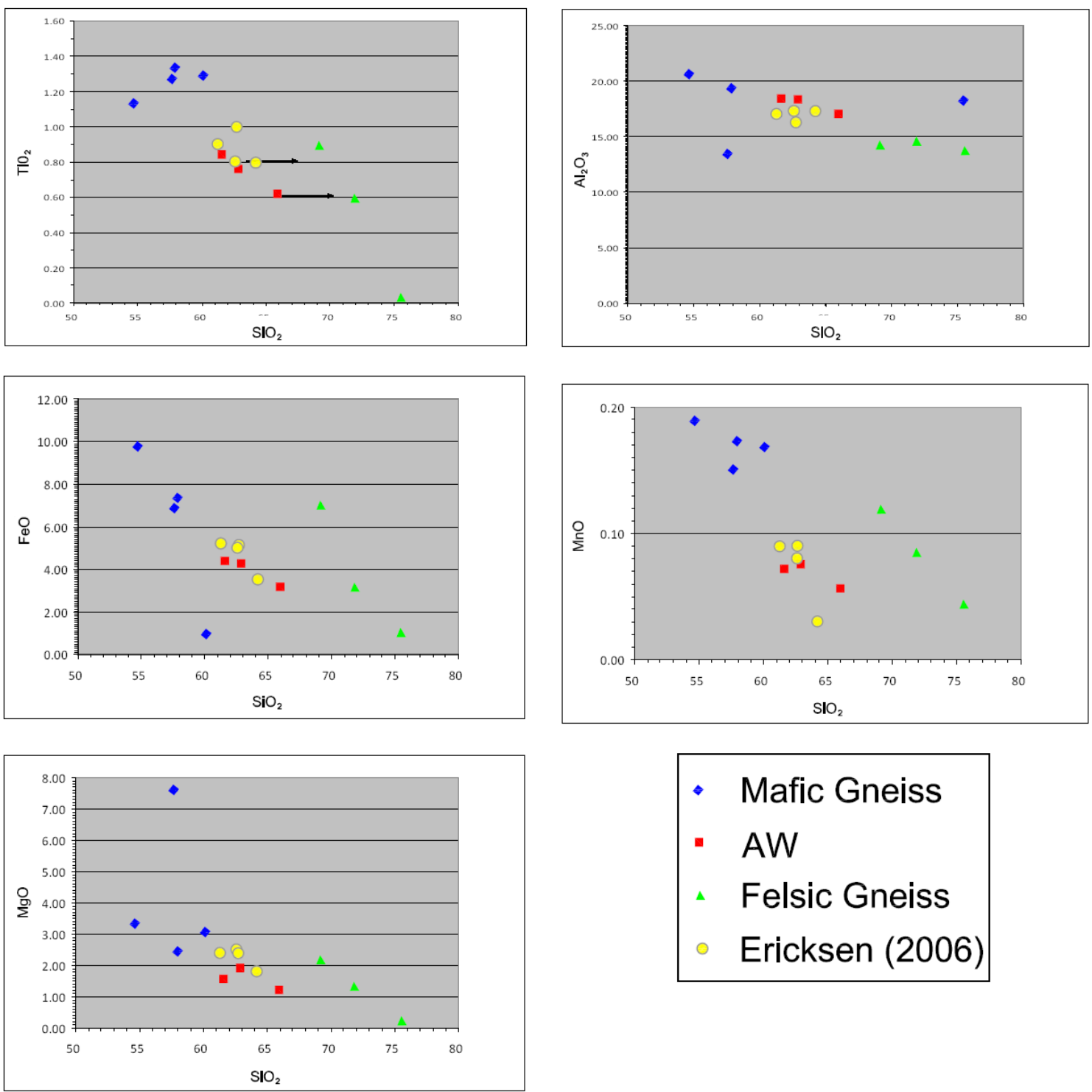

- Mafic Gneiss

- AW

$\triangle \quad$ Felsic Gneiss

- Ericksen (2006)

Figure 20. Major elements $\mathrm{TiO}_{2}, \mathrm{Al}_{2} \mathrm{O}_{3}, \mathrm{FeO}, \mathrm{MnO}$, and $\mathrm{MgO}$ versus $\mathrm{SiO}_{2}$. 

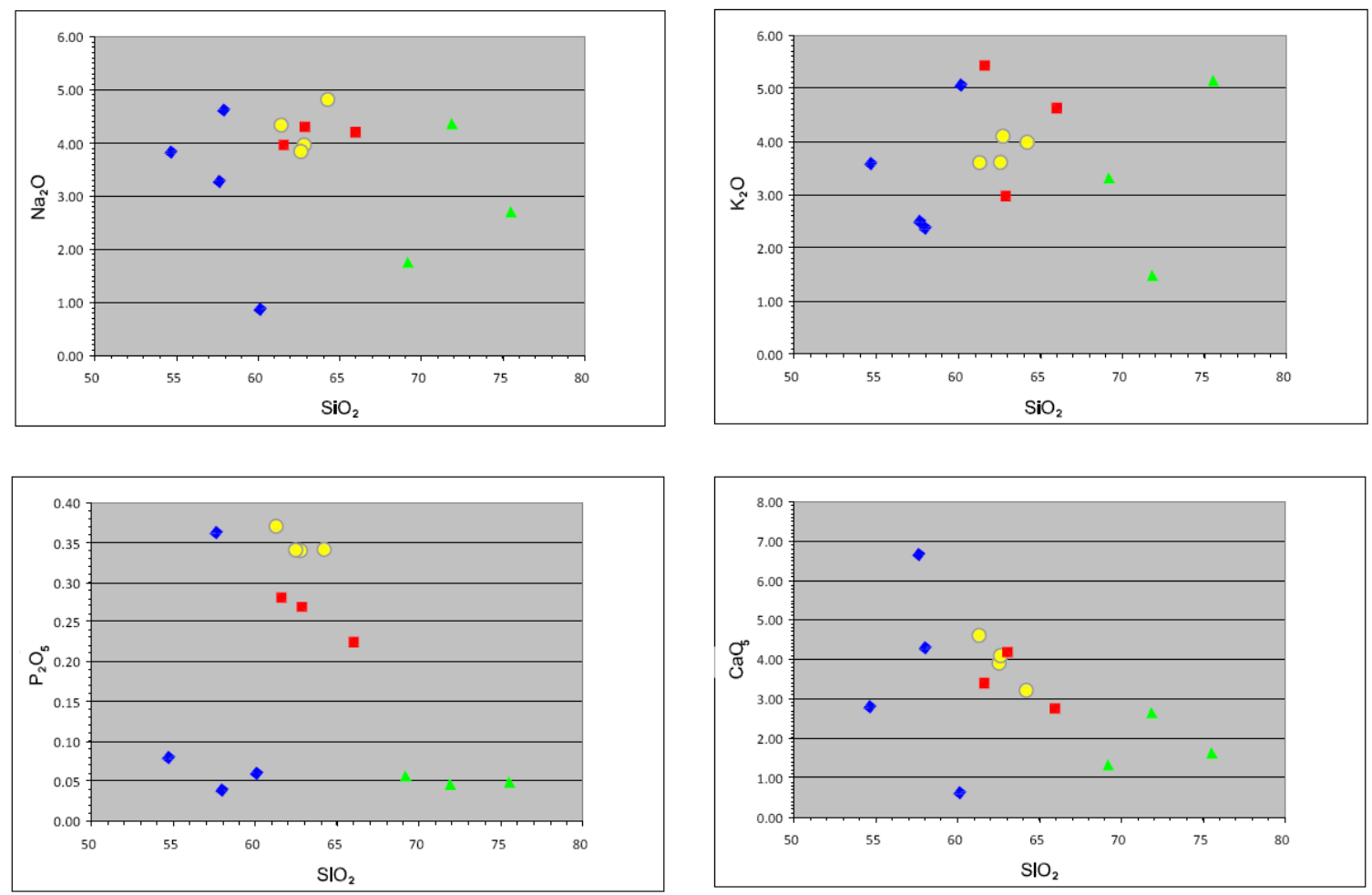

- Mafic Gneiss

- AW

- Felsic Gneiss

- Ericksen (2006)

Figure 21. Major elements $\mathrm{Na}_{2} \mathrm{O}, \mathrm{K}_{2} \mathrm{O}, \mathrm{P}_{2} \mathrm{O}_{5}$, and $\mathrm{CaO}$ versus $\mathrm{SiO}_{2}$. 

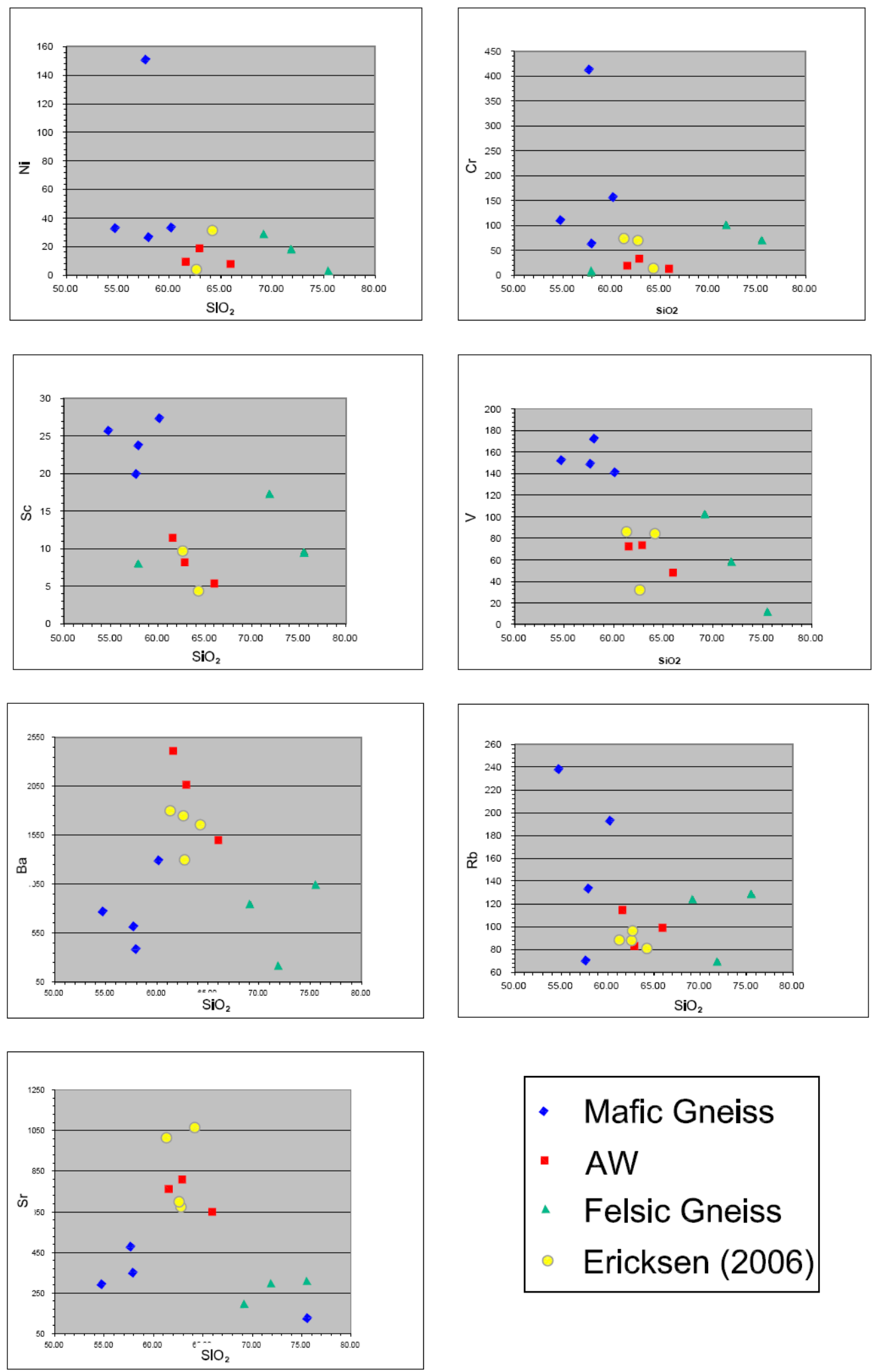

- Mafic Gneiss

- AW

$\triangle \quad$ Felsic Gneiss

- Ericksen (2006)

Figure 22. Trace elements $\mathrm{Ni}, \mathrm{Cr}, \mathrm{Sc}, \mathrm{V}, \mathrm{Ba}, \mathrm{Rb}$, and $\mathrm{Sr}$ versus $\mathrm{SiO}_{2}$. 

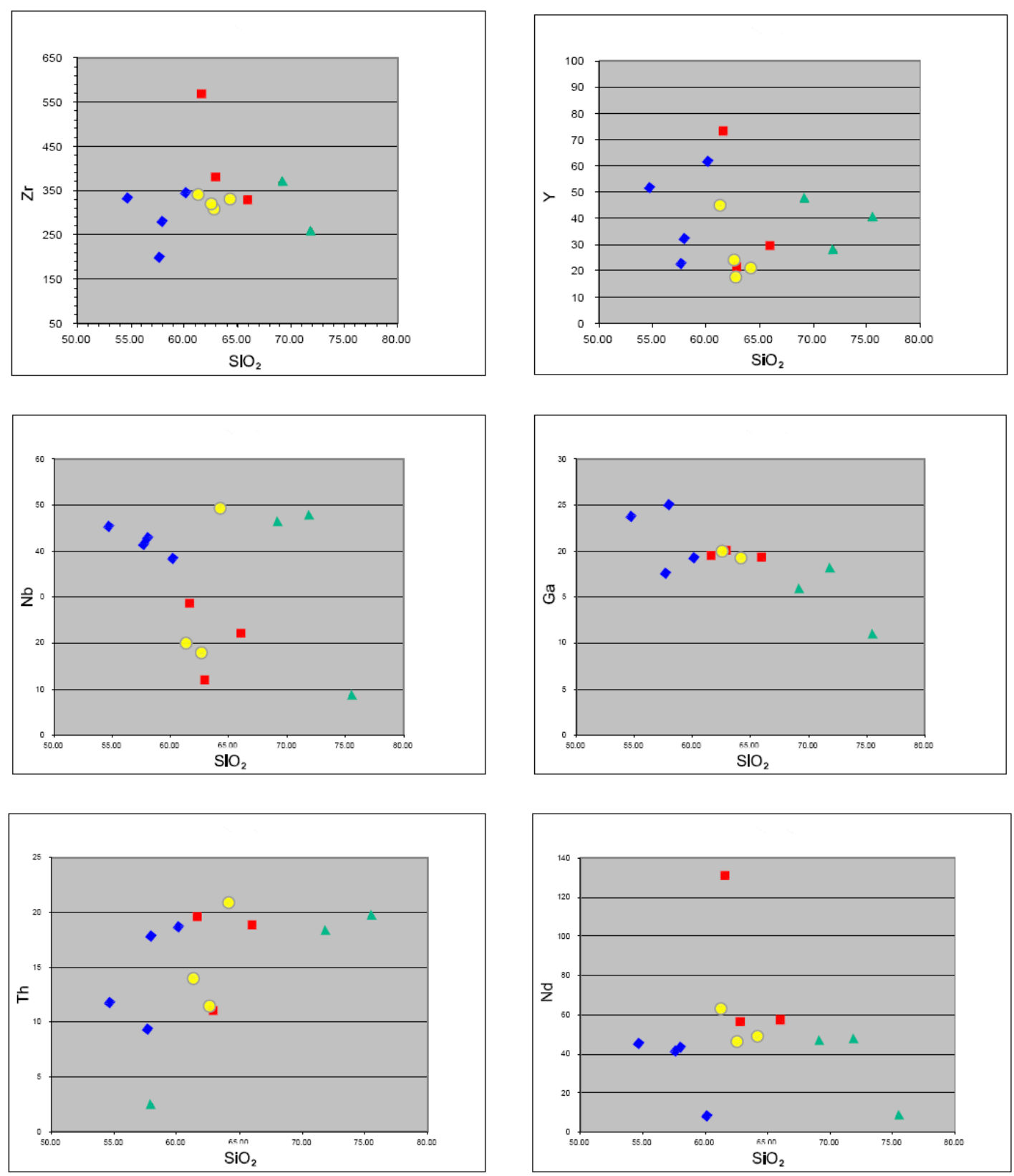

- Mafic Gneiss

- AW

^ Felsic Gneiss

- Ericksen (2006)

Figure 23. Trace elements $\mathrm{Zr}, \mathrm{Y}, \mathrm{Nb}, \mathrm{Ga}$, Th, and $\mathrm{Nd}$ versus $\mathrm{SiO}_{2}$. 
cumulate, the data collected from the suspected hybrid rocks in this study and those of Ericksen (2006) overlap, and are chemically indistinguishable. 


\section{DISCUSSION}

The central issues addressed by this study are the origin of the xenoliths, and the extent to which their displacement may have accommodated magma emplacement during the growth of the Aztec Wash pluton. As shown by field mapping and examination of the xenoliths in the study area, they are in almost every instance surrounded on all visible sides by plutonic material (Plate 1). Three competing hypotheses have been proposed to explain this relationship 1 ) the xenoliths are stoped blocks dislodged from the host rock margins (roof and walls) of the pluton and transported via gravity-induced downward movement through the magma body (e.g., Daly, 1903; Paterson et al., 1996; Pinotti et al., 2002; Yoshinobu et al., 2003; Zäk and Paterson, 2006) 2 ) magma pulses injected in a complex dike and sill network through Precambrian host rocks resulted in isolation of screens of gneiss, and, except for possibly some minor local rotation, the xenoliths have not been moved an appreciable distance by gravitational settling from their original site of origin (cf. Glazner and Bartley, 2006) 3 ) the xenoliths collapsed into the magma chamber as a result of destablization of the roof (and perhaps walls) during volcanic eruption (Hawkins and Wiebe, 2004) (e.g., by caldera collapse that accompanies magma chamber evacuation; Lipman, 1984). In cases (1) and (3), incorporation of xenoliths by stoping and by foundering of host rock xenoliths during volcanic eruption produce net transfer of host rock material downward under the influence of gravity. But xenolithfoundering during an eruption results in mass transfer of xenoliths from the roof (and possibly from walls) downward with magma evacuated onto the surface, whereas 
stoping, as traditionally defined, occurs only beneath the surface, displacing xenoliths down as magma moves upward (e.g., Lipman, 1984).

\section{Random Orientation of Foliations}

The inconsistency of host-rock fabric (foliations and lineations) in xenoliths within plutons is commonly used to argue for rotation of xenoliths in magma bodies, although the cause of the rotations has been interpreted in different ways (Glazner and Bartley, 2006; Yoshinobu and Barnes, 2006). The lack of a dominant and consistent foliation in the xenoliths within the pluton implies the xenoliths have been rotated from their original position prior to the solidification of the intrusion.

The most straightforward ways to produce the observed scatter of foliations are by stoping or by foundering of xenoliths during volcanic venting. Xenoliths dislodged from the margins of a magma body in either case are likely to be rotated during their descent through the magma (Paterson and Miller, 1988), particularly during volcanic venting if the eruptive style is explosive and magma is evacuated from a shallow magma chamber under turbulent flow conditions.

Rotation of xenoliths in situ during diking (as mentioned above; cf. Figure 8b in Glazner and Bartley, 2006) is considered unlikely in the case of the Aztec Wash pluton. Although in this scenario some small fragments may be spalled off and rotated during injection of magma (Glazner and Bartley, 2006), the larger xenoliths should be more consistently oriented from xenolith to xenolith. This is emphasized by examining possible correlations between xenolith size and fabric consistency. The three size classes 
described previously were plotted on separate stereographic projections (Plate 2). All block sizes show a random pattern of foliations, i.e., block size is uncorrelated with foliation orientation.

Mapping shows no strong pattern of size distribution with respect to vertical position within the pluton. A different pattern would be predicted if larger screens have been broken locally into xenoliths. The most obvious area where such might be the case in the Aztec Wash pluton is the large block of Ireteba granite at the eastern edge of the map area (Plate 1). There may be a slight concentration of larger blocks just above a mafic sheet sequence near the center of the map area, but in general, xenoliths of all sizes were found at all structural levels throughout the map area (Plate 2). There do appear to be "horizons" where xenoliths of varying sizes have concentrated against a viscosity barrier in the form of a mafic sheet. This observation and the observation that fabric orientations vary randomly regardless of xenolith size implies that the xenoliths are not derived by fracturing and rotation of in situ panels of host rock.

\section{Relationship of Host Rock Xenoliths to the Sheeted Sequences}

The general model for the development and growth of the Aztec Wash pluton shares many aspects with the Vinalhaven and other mafic-silicic layered intrusions in coastal Maine, such as Isle au Haut (Chapman and Rhodes, 1992), Pleasant Bay (Wiebe, 1993), and Cadillac Mountain, (Wiebe, 1994), in that the mafic sheeted sequences are interpreted to represent repeated injections of mafic magma onto an aggregating, crystal- 
rich granitic magma chamber floor. That the sheets are commonly separated by a thin monzonitic cumulate layer suggests there was enough time between mafic injections for some crystal settling to occur. The timescales are on the order of thousands to tens of thousands of years for Stoke's Law settling. However, loss of interstitial melt channeled upward through the granite pipes (filter pressing) is thought to mainly account for the "cumulate" compositional character (Harper et al., 2004).

The presence of host-rock xenoliths sandwiched between successive mafic sheets indicates that new mafic sheets were being injected during the same interval of time that xenoliths were settling, and suggests that material transfer by stoping partly made space for magma. The wrapping of mafic sheets around the upper (structural) surfaces of xenoliths (Fig. 24) is interpreted as draping, due to compaction of overlying material, within a sequential (i.e., "stratigraphic") succession of mafic sheets. In the few instances where the structurally lower contacts of meter-size and smaller xenoliths with sheets could be observed, there does not appear to be strong disruption or tearing of sheets (Plate 2). This suggests that xenoliths sank until encountering a relatively rigid surface. However, on a somewhat broader scale, sheeted sequences sometimes terminate along strike against xenolith-rich areas, suggesting larger-scale disruptions of sheets associated with xenoliths. In any case, blocks separated by a locally coherent sheet or sheet sequence represent discrete events of block incorporation into the Aztec Wash magma chamber (Figs. 24-27). A minimum of two separate events of xenolith incorporation has occurred, based on the clear-cut examples (e.g., Fig. 24) within the small area examined in detail in this study. It is likely that many such events have yet to be recognized in the 


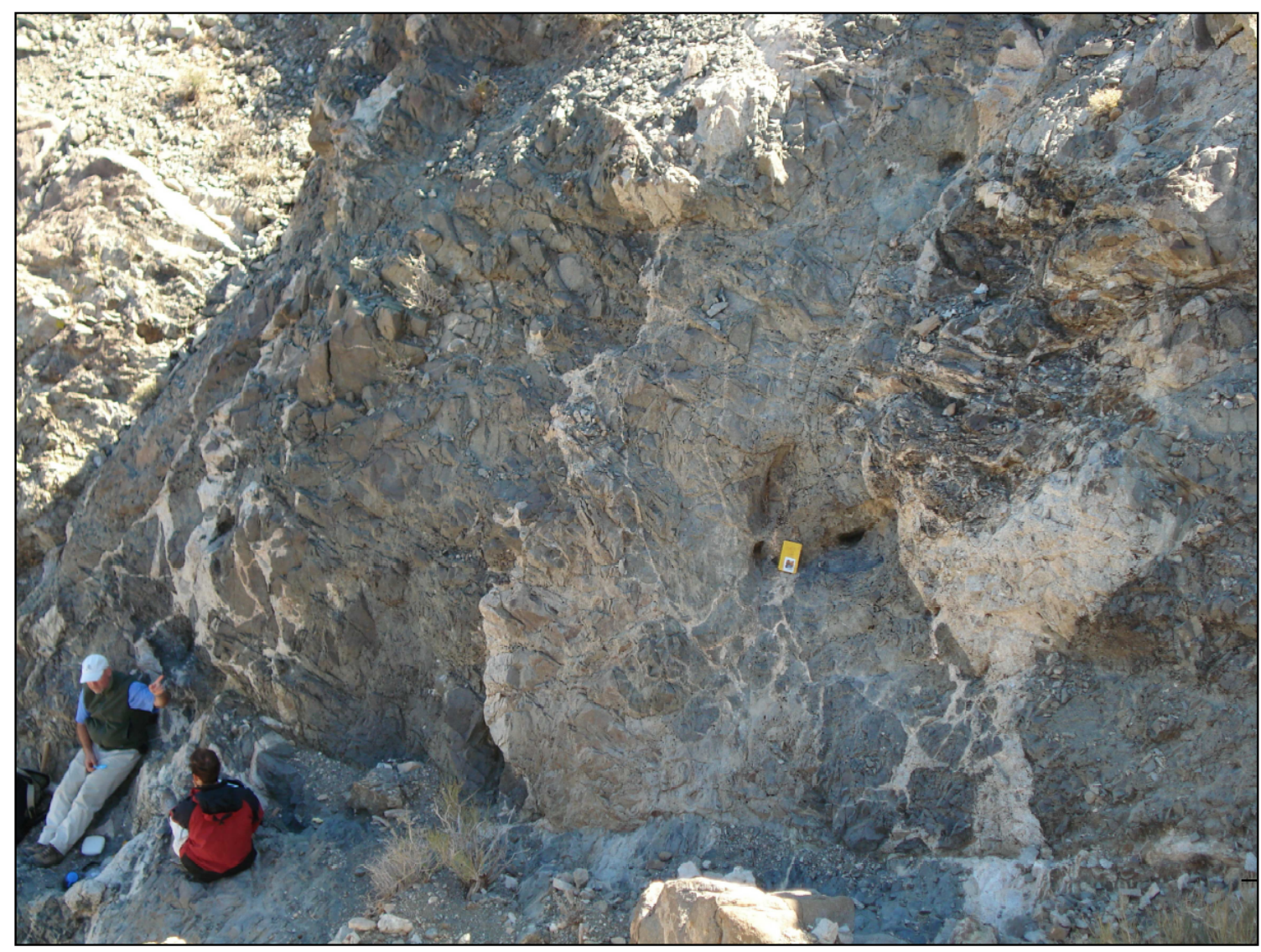

Figure 24. Mafic sheet draped over xenolith. Xenolith is situated within a cumulate sheet. See Fig. 25 for interpretation of photo. 


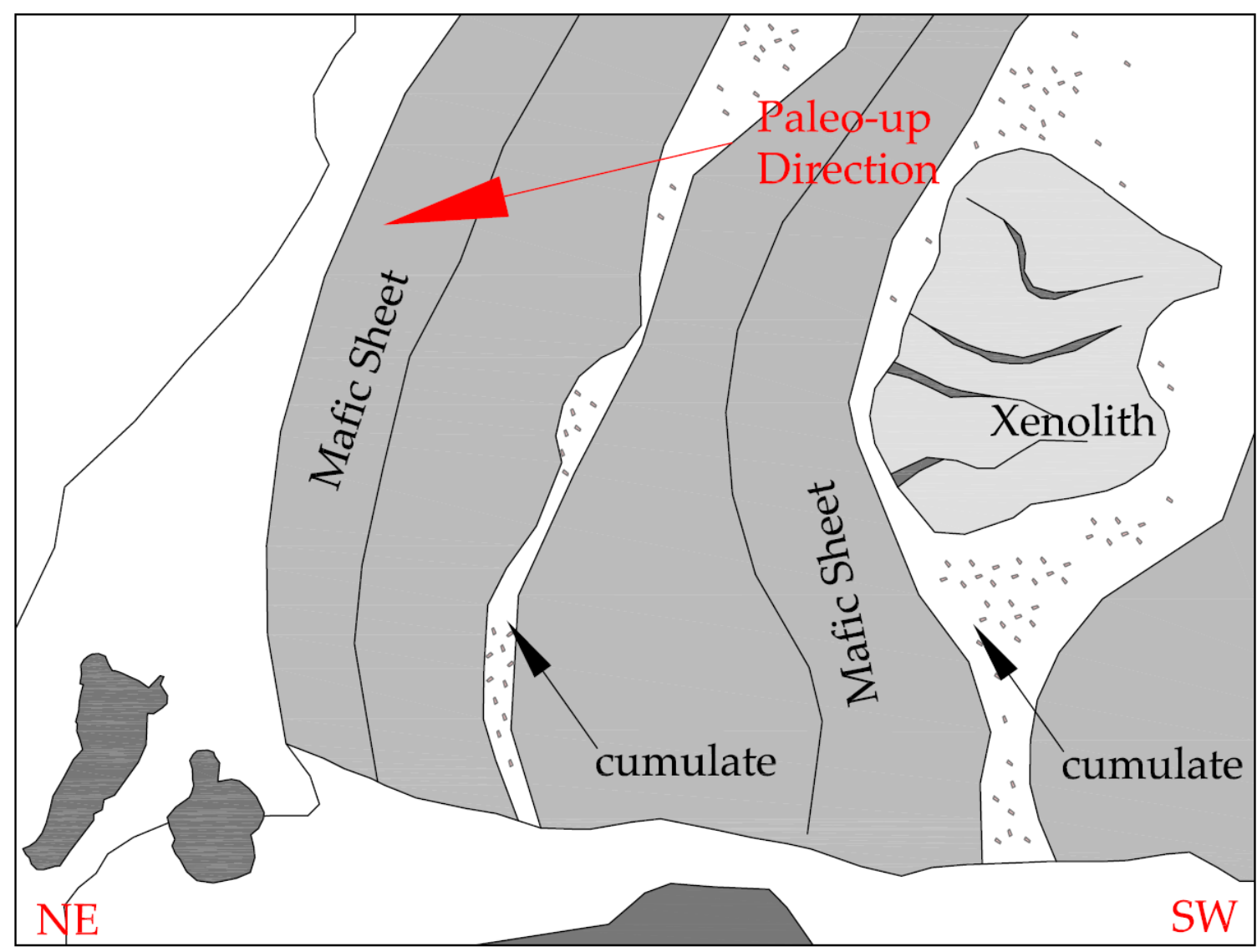

Figure 25. Cartoon diagram of mafic sheet draped over xenolith. Paleo-up direction established using pipe orientations and flame structures observed elsewhere in the study area. 


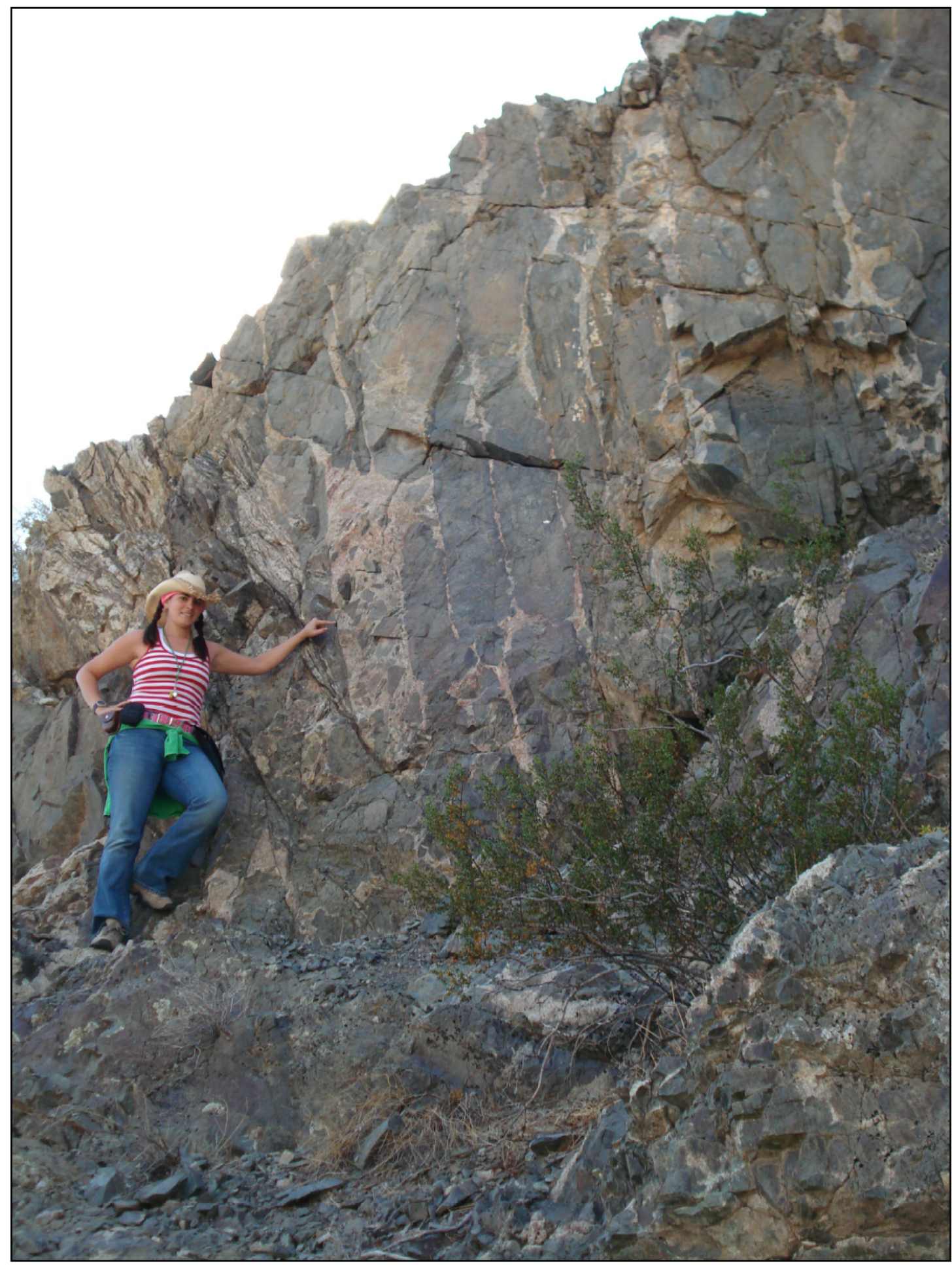

Figure 26. Steeply tilted mafic sheet sequence. Sequence showing mafic sheets and associated intrusive breccias and xenoliths. See Fig. 25 for interpretation of photo. 


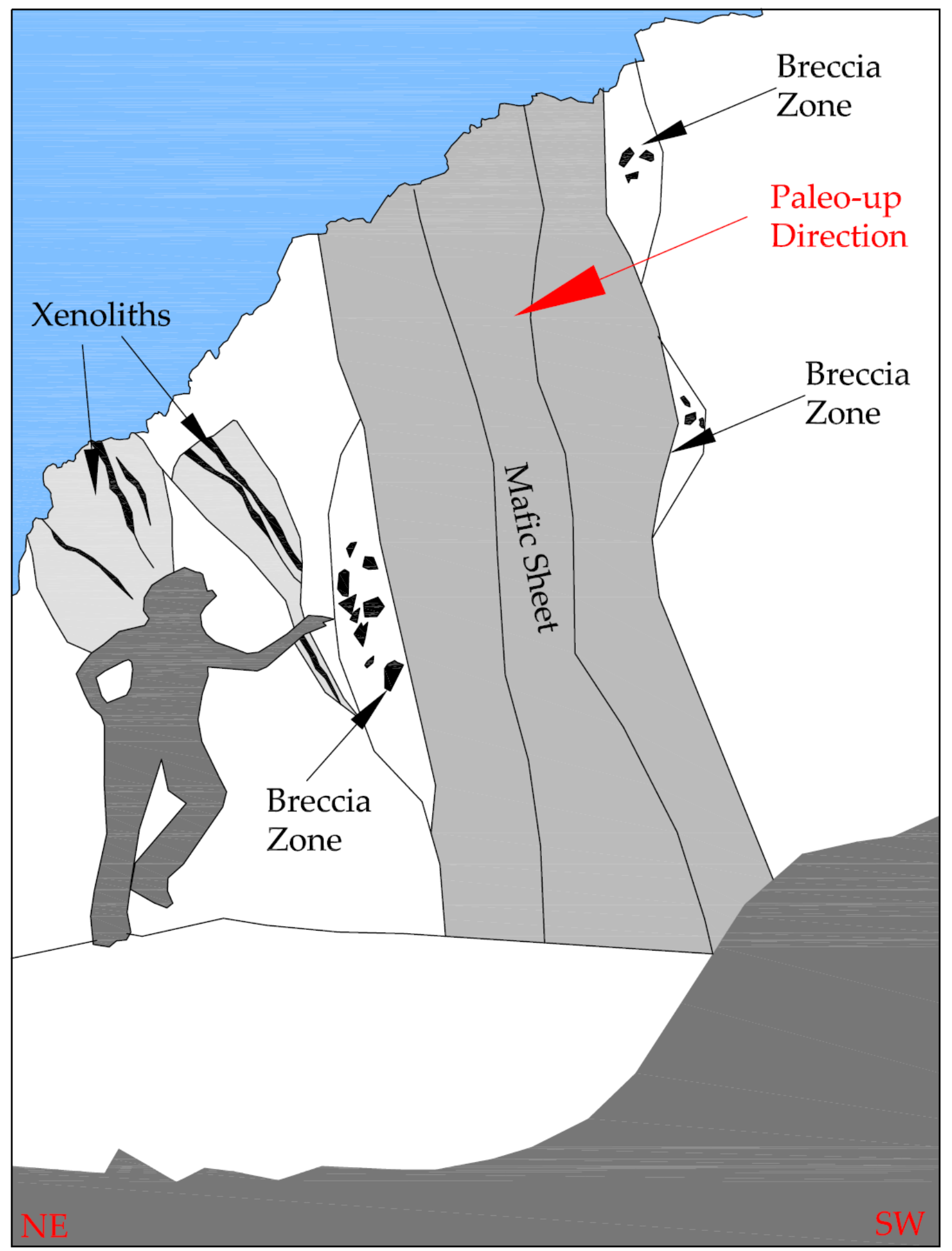

Figure 27. Cartoon diagram of steeply tilted mafic sheet sequence. Paleo-up direction established using pipe orientations and flame structures observed elsewhere in the study area. 
Aztec Wash pluton, especially given the size of the area within the Heterogeneous zone in which the host-rock blocks occur (Koteas, 2005).

Interpreting the xenoliths as in situ screens of host rock would require reinterpreting the entire Aztec Wash sheeted sequence as steeply dipping dikes. The field and structural work of previous studies, this study, and paleomagnetic evidence from the sheets (J. Faulds, pers. comm.) simply does not support such an interpretation. The "stratabound" blocks are important because they indicate that incorporation of blocks 1) occurred by gravitational settling through magma in an active magma chamber 2) did not all occur at the terminal stages of pluton solidification, and 3) did not remove so much heat from the magma chamber that it suffered thermal death (e.g., Glazner, 2007). The viscosity remained low enough and/or enough additional hot magma was introduced to allow for more blocks to be incorporated during growth of the pluton. If the magma chamber did not completely solidify during block incorporation, it at least permited xenoliths to be assimilated and therefore to influence the geochemical evolution of the magma chamber.

\section{Assimilation of Xenoliths}

The field evidence for disaggregation of host rock xenoliths is compelling in many areas (Figs. 4-7). The "wispy" tails of gneiss that stretch out into quartz monzonite and pinch out and interfingering of mafic biotite-rich gneiss bands and quartz monzonite suggest physical incorporation of xenoliths and xenocrysts derived from xenoliths. The 
common diffuse margins of many xenoliths also seem to indicate clear interaction and possibly thermal assimilation of host rock into Aztec Wash magmas (Figs. 4-7).

Xenoliths with diffuse boundaries that appear to show mixing of minerals derived from the margins of xenoliths into the pluton can be seen in thin section. But dissolution and resorption of magmatic crystals within the Aztec Wash pluton are widespread, so it is not always clear to what extent such features are the result of local assimilation of xenocrysts. In cases where obvious xenocrysts were observed, there was little evidence of dissolution. Evidence for specific mineral reactions that might indicate chemical modification by assimilation of host rock, such as biotite dehydration reactions in intact xenoliths, were not observed (Beard et al., 2005).

The major-element geochemistry of rocks that were suspected to be contaminated by host rock and compositionally similar rocks outside the area of xenoliths (Ericksen, 2006) show complete overlap: major elements show suspected contaminated and uncontaminated samples of Aztec Wash quartz monzonites plot in the same field and are chemically indistinguishable from one another. There is no obvious shift toward the bulk compositions of either the mafic or felsic gneisses that would be expected if bulk assimilation had occurred (Barnes et.al, 2004; Glazner and Bartley, 2006) (Table 1, Figs. 15-17).

Trace elements, which are potentially more sensitive to the effects of assimilation, also appear to indicate that quartz monzonites from xenolith-free areas differ little in their overall trace element budgets (Figs. 17 and 18). One compositional outlier has relatively high $\mathrm{Ba} / \mathrm{Zr}$, but this cannot be generated by contamination with host rock. Most likely, 
this rock experienced loss of residual granite melt and enrichment in K-feldspar component, as has been the case in many other quartz monzonitic rocks in Aztec Wash pluton.

The petrographic observations and major and trace element geochemistry together imply that thermal dissolution of xenoliths has not occurred, that "assimilation" is only manifest as very localized physical disaggregation of xenoliths, and that even such assimilation has had remarkably little impact on the composition of the Aztec Wash magmas at the scale of the sampling interval (several decimeters to meters from block contacts). It is possible that combined assimilation and fractional crystallization (AFC) would result in chemical trends that do not shift toward the contaminant (e.g., DePaolo, 1981), but the enthalpy requirements for this process in such a shallow magma system are prohibitive (e.g., Glazner, 2007). Isotopic measurements, which would provide the most robust means to detect chemical assimilation, have not been undertaken.

From the foregoing I conclude that Aztec Wash magmas and xenoliths were in contact with magma long enough to incipiently disaggregate along their margins, but not long enough to be chemically assimilated and change the composition of the magma appreciably. This conclusion also implies that the xenolith volume observed in the Aztec Wash pluton today more or less represents the total xenolith contribution (at the exposure depth and given the limitations in knowing the third dimension), and that there are no hidden or ghost xenoliths in the map area that have been assimilated and disaggregated (e.g., Clarke et al., 1998). 


\section{Wider Distribution of Xenolith Blocks in the Heterogeneous Zone}

One could argue that the sheets became disrupted as they injected around the screens of orthogneiss but it is difficult to imagine how the sheets themselves were “broken", fragmented, and otherwise disrupted during such a process. In fact the opposite is more likely, as one would expect the sheets to be continuous, although not necessarily straight. Even if dikes were to cut sharply across host rock fabrics and even to rotate xenoliths (cf. Fig. 8b in Glazner and Bartley, 2006), a diking model cannot explain opposite senses of rotation in adjacent xenoliths that are observed widely in the field area (Fig. 5). Some slumping and brecciation of sheets occur where they outcrop at the distal northern margins of the Heterogeneous zone. However, the degree of disruption seen in the xenolith-rich area is atypical in comparison to other interior parts of the Heterogenous zone that lack xenoliths.

On the other hand, if xenoliths disrupted pre-existing sheeted sequences the result would be discontinuous sheets at angles to each other in the areas of abundant xenoliths, to other sheeted sequences outside the xenolith-rich zones, and to gneiss block foliations, all of these relationships are observed. Also, sheets would only be disrupted in areas rich in xenoliths, which is consistent with field observations (Plate 3). In any case, the fact that the transition zone not only marks the lateral edge of the xenoliths (Koteas, 2005) but also an area where disruption of the sheeted sequences occurs implies that it must mark some sort of fundamental mechanical boundary. 


\section{Are the Xenoliths Stoped Blocks?}

The compelling evidence for downward transport of xenoliths through Aztec Wash magmas has been demonstrated in previous sections. But are these stoped blocks, and if so, did stoping constitute a significant space-making process during emplacement of the Aztec Wash pluton? Outside of the immediate map area, Koteas' (2005) mapping suggests that in areas where xenoliths occur, they make up much of the outcrop exposure of the pluton. There is no clear way to assess whether this gives an estimate of the \%age of space made by stoping for the Aztec Wash pluton. The strong lateral gradient in xenolith abundance in the Heterogeneous zone is especially hard to reconcile with stoping that might have occurred throughout the entire magma chamber. One critical question is whether this boundary is diachronous as would be suggested by the fact that it cuts across pluton "stratigraphy". If one accepts that xenoliths have been displaced downward under the influence of gravity, and through magma in multiple events, then this boundary must indeed be diachronous (Fig. 28).

The alternative is that the boundary represents some sort of catastrophic, abrupt disruption of the pluton that extended through it, perhaps a large volcanic eruption that not only evacuated magma but also mechanically tore apart deeper, older, and presumably mostly rigid portions of it. In this scenario, the xenoliths in the map area and at structurally deeper levels would essentially represent mega-breccias associated with one large eruption. It does not appear possible based on present data to completely rule out this scenario. However, my mapping suggests that, although they are disrupted, the 


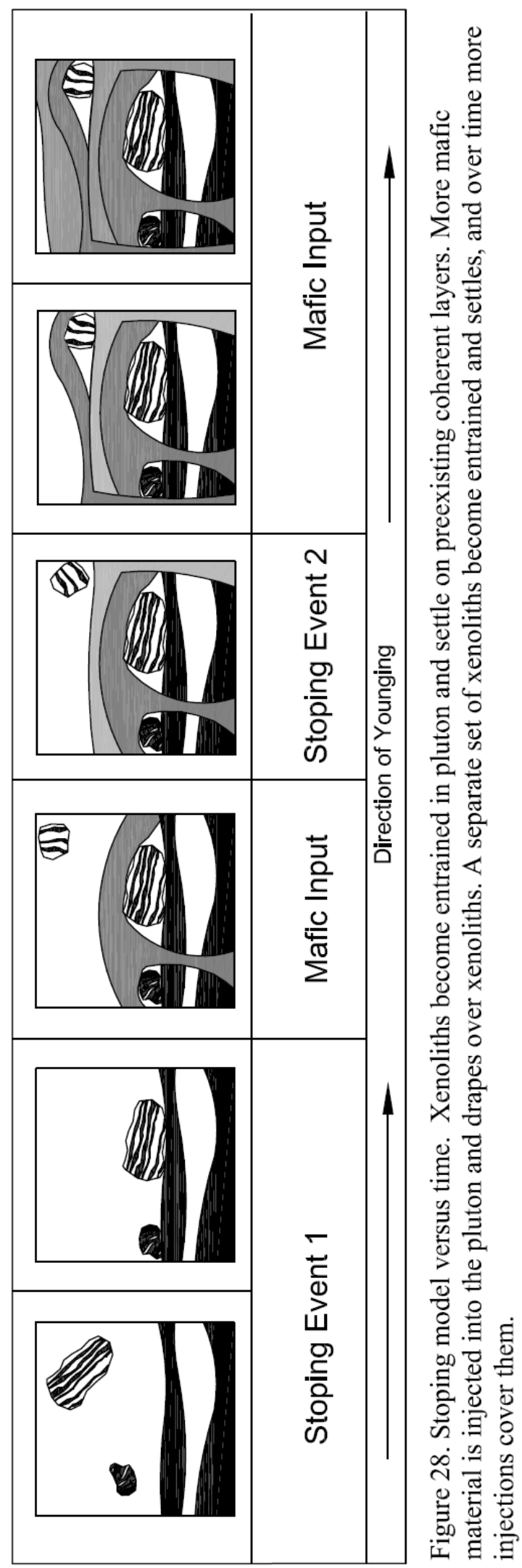


sheets are still traceable for modest distances, and have overall up directions that are consistent with less-disrupted areas in parts of the Hetergeneous zone where xenoliths do not occur.

The lobate geometry of the Heterogeneous zone suggests that the pluton grew in several major pulses of mafic sheet injection into a silicic magma chamber (Harper et al., 2004). Previous work by Faulds (2001) suggests most of the plutons in the CREC have erupted during their emplacement into the shallow crust, making roof collapse and stoping of xenoliths a viable possibility. The injections that formed the Heterogeneous zone may have also triggered volcanic eruptions, in which case roof and conduit destabilization would be expected. The large block of Ireteba granite that forms the eastern host-rock margin might also be related to roof subsidence, inasmuch as it appears to "protrude" down into the structurally deeper Aztec Wash pluton in the map area. That there were no obvious Ireteba xenoliths recognized beneath this large exposure in the map area suggests that it represents essentially one large mass that moved downward. The timing of overall emplacement of the Aztec Wash pluton also overlaps regional extension at this latitude, (Gans and Bohrson, 1998) so any brittle faulting above the pluton due to extension would tend to enhance foundering of roof rocks.

The following is my favored scenario describing the origin of xenoliths in the Aztec Wash pluton. It is based on field observations, foliation data, detailed mapping, and the key interpretation that the accumulating mafic sheet sequences represent, at least in a general way, a younging stratigraphy through the pluton. In the model (Fig. 29), magma was emplaced into host rocks of Precambrian crust intruded by Ireteba granite and began to form a magma chamber. Space, at least initially, was made by some 

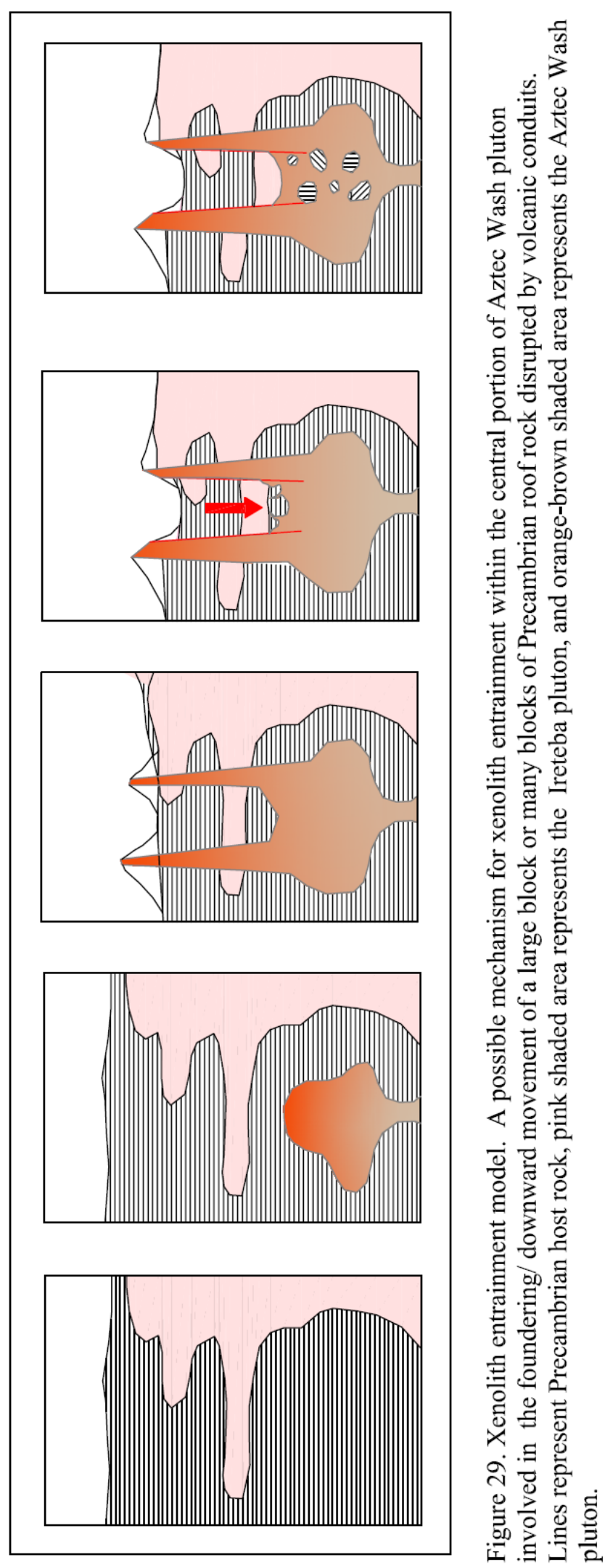
mechanism other than stoping, perhaps by extension and/or roof uplift. As the pluton grew by new injections into the active magma body periodic eruptions were triggered that destabilized material between vents or conduits. This produced mechanical break-up and foundering of the roof rocks, and disrupted previously formed sheets and other structures deeper and at the lateral extents of the pluton. The transfer of mass downward during volcanic eruption would presumably allow new magma accumulation at structurally higher levels, and above areas or domains in the pluton where xenoliths had settled. Final eruption(?) and solidification may have occurred coincidentally with foundering of the large block of Ireteba granite at the final pluton roof. These major disruptions may have coincided with the formation of new major lobes of the pluton. Although mass was transferred out on to the Earth's surface as xenoliths moved downward, if new magma was then emplaced above the xenoliths, and below the new roof, then these blocks would constitute stoped blocks. The model accommodates the distribution of xenoliths in the central/southern area of Aztec Wash pluton above the Pipe Canyon fault, which is generally viewed as closer to the feeder zone that fed the growing pluton (Harper et al., 2004), and thus may also have served to localize and/or focus volcanic venting.

How much mass was transferred out of Aztec Wash pluton is unknown, as definitive volcanic rocks associated with it have not been located. This makes estimating the amount of space created by stoping difficult to determine because mass transfer from the magma chamber to the surface is not strictly stoping. But if the interpretations above are correct, based on the total \%age of xenoliths from my mapping and that of Koteas (2005), space made due to stoping is conservatively on the order of $10 \%$. Thus, stoping in Aztec Wash pluton may not have been the primary way by which space was made to 
accommodate magma emplacememt, but it may have been appreciably more than the tiny estimates $(<<1 \%)$ postulated by Glazner and Bartley (2006) for all cases of stoping. 


\section{CONCLUSIONS}

It is unlikely, based on field observations, measurements, and mapping, that the xenoliths in the Aztec Wash pluton are screens. Xenolith foliation orientations strongly suggest xenoliths were incorporated into an active magma body. The relationship between xenoliths and disrupted sheeted sequences of the pluton also provide compelling evidence for stoping.

Although no evidence of large-scale or significant assimilation was discovered in the samples tested, the observation that xenoliths comprise approximately $30 \%$ of the outcrop in the map area, and that xenoliths were found separated by sheeted sequences formed in an active magma body indicate that stoping was a significant transfer process during late-stage pluton growth in the upper crust.

The separation of xenoliths by sheets, and the subsequent draping of sheets over xenoliths, prove that the incorporation of xenoliths occurred as multiple, rather than a single, event, and stoping of xenoliths did not cause the pluton to solidify completely.

Repeated volcanic eruption during growth of the pluton is consistent with the distribution of xenoliths, and structural relationships that are observed in the Aztec Wash pluton. 


\section{REFERENCES CITED}

Anderson, R. E., 1971, Thin skin distension in Tertiary rocks of southeastern Nevada: Geological Society of America Bulletin, v. 82, p. 43-58.

Bachl, C. A., Miller, C.F., Miller, J.S., and Faulds, J.E., 2001, Construction of a pluton: evidence from an exposed cross section of the Searchlight pluton, Eldorado Mountains, Nevada: Geological Society of America Bulletin, v. 113, p. 12131228 .

Barnes, C.G., Dumond, G., Yoshinobu, A.S., and Prestvik, T., 2004, Assimilation and crystal accumulation in a mid-crustal magma chamber: the Sausfjellet pluton, north central Norway: Lithos, v. 75 p. 389-412.

Beard, J.S., Ragland, P.C., and Crawford, M.L., 2005, Reactive bulk assimilation: A model for crust-mantle mixing in silicic magmas: Geology, v. 33, p. 681-684.

Bennet, V.C., and DePaolo, D.J., 1987, Proterozoic crustal history of the western United States as determined by Nd isotope mapping: Geological Society of America Bulletin, v. 99, p. 674-685.

Cates, N.L., 2003, Perspectives on the development of an intermediate, open-system magma chamber: Aztec Wash pluton. [M.S. thesis]: Vanderbilt University, 162 p.

Chapman, M., and Rhodes, J.M., 1992, Composite layering in the Isle au Haut Igneous Complex, Maine: Evidence for periodic invasion of mafic magma into an evolving magma reservoir: Journal of Volcanology and Geothermal Research, v. 51, p. 41-60.

Clarke, D., Henry, A., and White, M., 1998, Exploding xenoliths and the absence of 'elephant graveyards' in granite batholiths: Journal of Structural Geology, v. 20, p.1325-1343. 
Clarke, B.D., and Erdmann, S., 2008, Is stoping a volumetrically significant pluton emplacement process?: Comment: Geological Society of America Bulletin, V. 120, p. 1072-1074.

Coiner, L.V., 2003, Characterization of sheet structure in the Aztec Wash pluton, Nevada: Evidence for both cyclic deposition and vertical magma transport. [M.S. thesis]: Vanderbilt University, $112 \mathrm{p}$.

Cruden, A. R., 1990, Flow and fabric development during the diapiric rise of magma: Journal of Geology, v. 98, p. 681-698.

Cruden, A.R., and McCafrey, K.J.W., 2001, Growth of plutons by floor subsidence: implications for rates of emplacement, intrusion spacing and melt-extraction mechanisms. Physics and Chemistry of the Earth, Part A, Solid Earth and Geodesy, v. 26, p. 303-315.

Daly, R. A., 1903, The mechanics of igneous intrusion: American Journal of Science, v. 16, p. 107-126.

DePaolo, D. J., 1981, Trace element and isotopic effects of combined wall-rock assimilation and fractional crystallization: Earth and Planetary Science Letters, v. 53, p. 189-202.

Dumond, G., Yoshinobu, A.S., and Barnes, C.G., 2005, Mid-crustal emplacement of the Sausfjellet pluton, central Norway: ductile flow, stoping and in situ assimilation: Geological Society of America Bulletin, v. 117, no. 3/4, p. 383-395.

Ericksen, M., 2006, Fractionation, recharge and hybridization in a shallow, bimodal magma reservoir. [M.S. thesis]: San Jose State University, 117 p. 
Falkner, C., M., Miller, C.F., Wooden, J.L., and Heizler, M.T., 1995, Petrogenesis and tectonic significance of the calc-alkaline, bimodal Aztec Wash pluton, Eldorado Mountains, Colorado River extensional corridor: Journal of Geophysical Research, v. 100, P. 10,453-10,476.

Faulds, J.E., Geissman, J.W., and Mawer, C.K., 1990, Structural development of a major extensional accommodation zone in the Basin and Range province, northwestern Arizona and southern Nevada: Geological Society of America Memoir, v. 176, p. $37-76$.

Faulds, J.E., Geissman, J.W., and Shafiqullah, M., 1992, Implications of paleomagnetic data on Miocene extension near a major accommodation zone in the Basin and Range province, northwestern Arizona and southern Nevada: Tectonics, v. 11, p. 204-227.

Faulds, J.E., Feuerbach, D.L., Reagan, M., Metcalf, R.V., Gans, P., and Walker, J.D., 1995, The Mount Perkins block, northwestern Arizona: An extended cross section of an evolving, preextensional to synextensionaly magmatic system: Journal of Geophysical Research, v. 100, no. B8, p. 15,249-16,266.

Faulds, J. E., Feuerbach, D.L., Miller, C. F., and Smith, E.I., 2001, Cenozoic evolution of the northern Colorado River Extensional Corridor, southern Nevada and northwest Arizona, Utah: Geological Association Publication 30- Pacific Section American Association of Petroleum Geologists Publication GB78, p. 239-271.

Gans, P.B., and Bohrson, W.A., 1998, Suppression of volcanism during rapid extension in the Basin and Range Province, United States: Nature, v. 279, p. 66-68.

Glazner, A.F., 2007, Thermal limitations on incorporation of wall rock into magma: Geology, v. 35, p. 319-322.

Glazner, A.F., and Bartley, J.M., 2006, Is stoping a volumetrically significant pluton emplacement process?: GSA Bulletin, v. 118, no. 9/10, p. 1185-1195. 
Grocott, J., Arevalo, C., Welkner, D., and Cruden, A.R., 2009, Fault assisted vertical pluton growth: Coastal Cordillera, northern Chilean Andes: Journal of the Geological Society of London, v. 166, p. 295-301.

Harper, B.E., Miller, C. F., Koteas, G. C., Cates, N. L., Wiebe, R.A., Lazzareschi, D.S., and Cribb, J.W. 2004, Granites, dynamic magma chamber processes and pluton construction: the Aztec Wash pluton, Eldorado Mountains, Nevada, USA: Earth Sciences, v. 95, p. 277-295.

Hawkins, D.P., and Wiebe, R.A., 2004, Discrete stoping events in granitic plutons: A signature of eruptions from silicic magma chambers?: Geology, v.32, p. 10211024.

Howard, K., A., and John, B.E., 1987, Crustal extension along a rooted system of imbricate low angle faults: Colorado River Extensional Corridor, California and Arizona. in: Coward, M.P., Dewet, J.F., Hancock, P.L., eds., Continental Extensional Tectonics. Geological Society Special Publication v. 28, p. 299-311.

Koteas, G.C., 2005, Documenting the architecture of a stratified, multiply recharged intrusion. [M.S. thesis]: Vanderbilt University, 103 p.

Lipman, P.W., 1984, The roots of ash flow calderas in western North America; windows into the tops of granite batholiths: Journal of Geophysical Research, v. 89, p. 8801-8841.

Marsh, B. D. 1982, On the mechanics of igneous diapirism, stoping, and zone melting: American Journal of Science, v. 282, p. 808-855.

Miller C., F., Miller, J.S., and Faulds, J.E., 2005, Miocene volcano-plutonic systems, southern Nevada: a window into upper crustal magmatic processes: Pacific Section- Society of Sedimentary Geology, v. 99, p. 37-66.

Miller, C. F., and Miller, J.S. 2002, Contrasting stratified plutons exposed in tilt blocks, Eldorado Mountains, Colorado River Rift, NV, USA: Lithos, v. 61, p. 209-224. 
Miller, R.B., and Paterson, S.R., 1999, In defense of magmatic diapirs: Journal of Structural Geology, v. 21, p. 1161-1173.

Patrick, D.W., and Miller, C.F. 1997, Processes in a composite, recharging magma chamber; evidence from magmatic structures in the Aztec Wash pluton: Proceedings of the 30th International Geological Congress, v. 30, p. 121-135.

Paterson, S.R., Fowler, T.K., and Miller, R.B., 1996, Pluton emplacement in arcs: a crustal-scale exchange process. Transactions of the Royal Society of Edinburgh: Earth Sciences, v. 87, p. 115-123.

Paterson, S.R., and Miller, R.B., 1988, Stoped blocks in plutons: paleo-plumb bobs, viscometers or chronometers?: Journal of Structural Geology, v. 20, p. 12611272 .

Paterson, S.R., Vernon, R.H., and Fowler, T.K., Jr., 1991, Aureole tectonics, in Kerrick, D.M., ed., Contact Metamorphism: Reviews in Mineralogy: Mineralogical Society of America, v. 26, p.673-722.

Paterson, S.R., Pignotta, G.S., Farris, D., Memeti, V., Miller, R.B, Vernon, R.H., and Žák, J., 2008, Is stoping a volumetrically significan pluton emplacement process? Discussion: Geological Society of American Bulletin, v. 120, p. 1075-1079.

Pignotta, G.S., and Paterson, S.R., 2007, Voluminous stoping in the Mitchell Intrusive Suite, Sierra Nevada batholith, California: Canadian Mineralogist, v. 45, p. 87106.

Pinotti, L.P., Coniglio, J.E., Esparza, A.M., D’Eramo, F.I., and Llambias, E.J., 2002, Nearly circular plutons emplaced by stoping at shallow crustal levels, Cerro Aspero Batholith, Sierras Pampeanas de Coroba, Argentina: Journal of South American Earth Sciences, v. 15, p. 251-265. 
Pitcher, W.S., and Bussell, M.A., 1977, Structural control of batholith emplacement in Peru; a review: Journal of the Geological Society of London, v. 133, p. 249-256.

Robinson, D.M., and Miller, C.F., 1999, Record of magma chamber processes preserved in accessory mineral assemblages: American Minerologist, v. 84, p. 1346-1353.

Tikoff, B., and Teyssier, C., 1992, Crustal scale en echelon "P-shear" tension bridges: A possible solution to the batholithic room problem: Geology, v. 20, p. 927-930.

Tikoff, B., and Teyssier, C., 1999, Translation and the resolution of the pluton space problem: Journal of Structural Geology, v. 21, p. 1109-1117.

Titus, S., J., Clarke, R., and Tikoff, B., 2005, Geologic and geophysical investigation of two fine grained granites, Sierra Nevada Batholith, California: Evidence for structural controls on emplacement and volcanism: Geological Society of America Bulletin, v. 117, p. 1256-1271.

Volborth, A., 1973, Geology of the granite complex of the Eldorado, Newberry, and northern Dead Mountains, Clark County, Nevada: Nevada Bureau of Mines and Geology Bulletin, v. 80, scale 1:125,000, 1 Sheet, 40 p. text.

Washington State University, 2011, School of Earth and Environmental Sciences Lab, Technical Notes: http://www.sees.wsu.edu/Geolab/note.html (October, 2011)

Walker, B. A., Miller, C.F., Lowery Claiborne, L., Wooden, J.L., and Miller, J.S., 2007, Geology and geochronology of the Spirit Mountain batholith, southern Nevada: Implications for the timescales and physical processes of batholith construction: Journal of Volcanology and Geothermal Research, v. 167, p. 239-262.

Wiebe, R. A., 1993, The Pleasant Bay layered gabbro-diorite, coastal Maine: Ponding and crystallization of basaltic injections in a silicic magma chamber: Journal of Petrology, v., 34, p. 461-489. 
Wiebe, R.A., 1994, Silicic magma chambers as traps for basaltic magmas: The Cadillac Mountain intrusive complex, Mount Desert Island, Maine: Journal of Geology, v. 102 , p. $423-437$

Wiebe, R.A., and Collins, W.J., 1998, Depositional features and stratigraphic sections in granitic plutons: implications for the emplacement and crystallization of granitic magma: Journal of Structural Geology, v. 20 no. 9/10, p. 1273-1289.

Wooden, J., and Miller, D., 1990. Chronological and isotopic framework for early Proterozoic crustal evolution in the eastern Mojave Desert region, SE Califonia: Journal of Geophysical Research, v. 95, p. 20133-20146.

Yoshinobu, A.S., Fowler, T.K., Paterson, S.R., Llambias, E., Sato, A., and Tickji, H., 2003, A view from the roof; magmatic stoping in the shallow crust, Chita pluton, Argentina: Journal of Structural Geology, v. 25, p. 1037-1048.

Yoshinobu, A.S., and Barnes, 2008, Is stoping a volumetrically significant pluton emplacement process: Discussion: Geological Society of America Bulletin, v. 120, p. 1080-1081.

Žák, J., and Paterson, S.R. 2006. Roof and walls of the Red Mountain Creek Pluton, eastern Sierra Nevada Mountains (USA): implications for process zones during pluton emplacement: Journal of Structural Geology, v. 28, p. 575-587. 